\title{
CovidNudge: diagnostic accuracy of a novel lab-free point-of-care diagnostic for SARS-CoV-2
}

\section{AUTHORS}

Malick M Gibani (D.Phil) ${ }^{* 1,2}$, Prof. Christofer Toumazou (Ph.D)*3,4, Mohammadreza Sohbati (Ph.D) Rashmita Sahoo (Ph.D) ${ }^{3}$, Maria Karvela (Ph.D)3, Tsz-Kin Hon (Ph.D) ${ }^{3}$, Sara De Mateo (Ph.D) ${ }^{3}$, Alison Burdett (Ph.D) $)^{4}$, K Y Felice Leung (Ph.D) $)^{3}$, Jake Barnett (Ph.D) ${ }^{3}$, Arman Orbeladze (MSc) ${ }^{3}$, Song Luan $(\mathrm{Ph} . \mathrm{D})^{3}$, Stavros Pournias (MSc) ${ }^{3}$, Jiayang Sun (MSc) ${ }^{3}$, Barnaby Flower (MRCP) $)^{1,2}$, Judith Bedzo-Nutakor $(\mathrm{BSc})^{3}$, Maisarah Amran (MBBS) ${ }^{2}$, Rachael Quinlan (BSc) ${ }^{1}$, Keira Skolimowska (Ph.D) $)^{1,2}$, Robert Klaber $(\mathrm{MD})^{2}$, Gary Davies (MD) ${ }^{5}$, David Muir (FRCPath) ${ }^{2}$, Paul Randell (FRCPath) ${ }^{2}$, Prof. Derrick Crook (FRCPath) ${ }^{6}$, Prof. Graham P Taylor (DSc) ${ }^{1}$, Prof. Wendy Barclay (Ph.D) ${ }^{1}$, Nabeela Mughal (FRCPath) ${ }^{1,2,5}$, Luke S P Moore (Ph.D)1,2,5, Katie Jeffery (Ph.D) ${ }^{6,7}$, Prof. Graham S Cooke (FRCP) $)^{1,2}$

\section{AFFILIATIONS}

1 - Department of Infectious Disease, Imperial College London, United Kingdom

2 - Imperial College Healthcare NHS Trust, United Kingdom.

3 - DnaNudge Ltd, Translation and Innovation Hub, Imperial College White City Campus, London

4 - Department of Electrical and Electronic Engineering, Imperial College London

5 - Chelsea \& Westminster NHS Foundation Trust, London

6 - Nuffield Department of Medicine, Oxford University, Oxford, United Kingdom

7 - Oxford University Hospitals NHS Foundation Trust, Oxford, United Kingdom

\section{Corresponding Author:}

Professor Graham Cooke, Department of Infectious Disease, Imperial College London, W21NY g.cooke@imperial.ac.uk

\section{Key Words:}

SARS-CoV-2, COVID-19, point-of-care diagnostics 
medRxiv preprint doi: https://doi.org/10.1101/2020.08.13.20174193; this version posted August 15, 2020. The copyright holder for this preprint (which was not certified by peer review) is the author/funder, who has granted medRxiv a license to display the preprint in It is made available under a CC-BY-NC-ND 4.0 International license.

\section{ABSTRACT}

\section{Background}

Access to rapid diagnosis is key to the control and management of SARS-CoV-2. Reverse TranscriptasePolymerase Chain Reaction (RT-PCR) testing usually requires a centralised laboratory and significant infrastructure. We describe the development and diagnostic accuracy assessment of a novel, rapid pointof-care RT-PCR test, the DnaNudge ${ }^{\circledR}$ platform CovidNudge test, which requires no laboratory handling or sample pre-processing.

\section{Methods}

Nasopharyngeal swabs are inserted directly into a cartridge which contains all reagents and components required for RT-PCR reactions, including multiple technical replicates of seven SARS-CoV-2 gene targets $(r d r p 1, r d r p 2$, e-gene, $n$-gene, $\mathrm{n} 1, \mathrm{n} 2$ and $\mathrm{n} 3)$ and human ribonuclease $\mathrm{P}$ (RNaseP) as positive control. Between April and May 2020, swab samples were tested in parallel using the CovidNudge direct-to-cartridge platform and standard laboratory RT-PCR using swabs in viral transport medium. Samples were collected from three groups: self-referred healthcare workers with suspected COVID-19 (Group 1, n=280/386; 73\%); patients attending the emergency department with suspected COVID-19 (Group 2, $n=15 / 386 ; 4 \%$ ) and hospital inpatient admissions with or without suspected COVID-19 (Group 3, n=91/386; 23\%).

\section{Results}

Of 386 paired samples tested across all groups, 67 tested positive on the CovidNudge platform and 71 with standard laboratory RT-PCR. The sensitivity of the test varied by group (Group $193 \%$ [84-98\%], Group 2 100\% [48-100\%] and Group 3 100\% [29-100\%], giving an average sensitivity of $94.4 \%$ (95\% confidence interval 86-98\%) and an overall specificity of $100 \%$ (95\%CI 99-100\%; Group $1100 \%$ [98-100\%]; Group 2 $100 \%$ [69-100\%] and Group $3100 \%$ [96-100\%]). Point of care testing performance was comparable during a period of high (25\%) and low (3\%) background prevalence. Amplification of the viral nucleocapsid (n1, $\mathrm{n} 2, \mathrm{n} 3)$ targets were most sensitive for detection of SARS-CoV2, with the assay able to detect $1 \times 10^{4}$ viral particles in a single swab.

\section{Conclusions}

The CovidNudge platform offers a sensitive, specific and rapid point of care test for the presence of SARSCoV-2 without laboratory handling or sample pre-processing. The implementation of such a device could be used to enable rapid decisions for clinical care and testing programs. 
medRxiv preprint doi: https://doi.org/10.1101/2020.08.13.20174193; this version posted August 15, 2020. The copyright holder for this preprint (which was not certified by peer review) is the author/funder, who has granted medRxiv a license to display the preprint in It is made available under a CC-BY-NC-ND 4.0 International license

\section{RESEARCH IN CONTEXT}

\section{Evidence before this study}

The WHO has highlighted the development of rapid, point-of-care diagnostics for detection of SARSCoV-2 as a key priority to tackle COVID-19. The Foundation for Innovative Diagnostics (FIND) has identified over 90 point-of-care, near patient or mobile tests for viral detection of SARS-CoV-2. However, the most widely available rapid tests to date require some sample handling which limits their use at pointof-care. In addition, pressure on supply chains is restricting access to current diagnostics and alternatives are needed urgently.

\section{Added value of this study}

We describe the development and clinical validation of COVID nudge, a novel point-of-care RT-PCR diagnostic, evaluated during the first wave of the SARS-CoV-2 epidemic. The platform is able to achieve high analytic sensitivity and specificity from dry swabs within a self-contained cartridge. The lack of downstream sample handling makes it suitable for use in a range of clinical settings, without need for a laboratory or specialized operator. Multiplexed assays within the cartridge allow inclusion of a positive human control, which reduces the false negative testing rate due to insufficient sampling.

\section{Implication of the available evidence}

Point-of-care testing can relieve pressure on centralized laboratories and increase overall testing capacity, complementing existing approaches. These findings support a role for COVID Nudge as part of strategies to improve access to rapid diagnostics to SARS-CoV-2. Since May 2020, the system has been implemented in UK hospitals and is being rolled out nationwide. 
medRxiv preprint doi: https://doi.org/10.1101/2020.08.13.20174193; this version posted August 15, 2020. The copyright holder for this preprint (which was not certified by peer review) is the author/funder, who has granted medRxiv a license to display the preprint in It is made available under a CC-BY-NC-ND 4.0 International license .

\section{INTRODUCTION}

1 Since its emergence in December 2019, SARS-CoV-2 has led to over 18,000,00 confirmed cases of

2 COVID-19 and 700,000 deaths by the end of July 2020.1,2 Improved access to diagnostics is key to

3 controlling ongoing transmission. The viral load in the upper respiratory tract appears to be highest at - or

4 shortly before - the onset of symptoms ${ }^{3-5}$ and the majority of patients with COVID-19 are diagnosed 5 using reverse transcriptase polymerase chain reaction (RT-PCR) from nasopharyngeal and/or 6 oropharyngeal swabs.

8 Since the publication of the first genome sequence, several in-house and commercial diagnostic kits have 9 been deployed globally. ${ }^{6,7}$ Laboratory RT-PCR remains the standard of care for detection of SARS-CoV-2, 10 although false negative tests can occur in patients presenting with a clinical syndrome compatible with 11 COVID-19. ${ }^{8}$ However, standard RT-PCR is time-consuming and - where they are available - the technical 12 requirements usually require centralized diagnostic laboratories. Laboratory based tests typically take 4-6 13 hours to complete, and the transport of clinical samples can mean the turnaround time is frequently over 1424 hours, ${ }^{9}$ potentially resulting in delay to diagnosis and inappropriate infection control precautions. An 15 additional limitation to several commercial kits is the lack of a human gene target to control for sample 16 adequacy control (such as Ribonuclease P, RNaseP), thereby failing to identify inadequate samples and contributing to false negative results..$^{10,11}$

19 Point-of-care (POC) diagnostics can have an impact on patient management and control of infectious 20 disease epidemics ${ }^{12}$ and were identified by a WHO expert group as the first of eight research priorities in response to the COVID-19 outbreak. ${ }^{13}$ POC diagnostics accelerate clinical decision making, enabling 22 effective triage and timely therapeutic and infection control interventions ${ }^{14}$ alleviating pressure on 23 overburdened centralized labs and allowing testing in community settings. However, many existing POC

24 diagnostics still require some sample processing which limit their use.9,15 
medRxiv preprint doi: https://doi.org/10.1101/2020.08.13.20174193; this version posted August 15, 2020. The copyright holder for this preprint (which was not certified by peer review) is the author/funder, who has granted medRxiv a license to display the preprint in It is made available under a CC-BY-NC-ND 4.0 International license .

26 In response to the SARS-CoV-2 pandemic, the CovidNudge ${ }^{\circledR}$ point-of-care platform (DnaNudge Ltd,

27 UK) was redesigned, from its previous commercial use in human DNA typing, to provide true sample-toanswer multiplex RT-PCR diagnosis of SARS-CoV-2, without the need for any laboratory facilities and trained personnel.16,17 To assess the performance of this novel diagnostic platform we conducted a diagnostic accuracy study for the diagnosis of SARS-CoV-2 infection against laboratory-based RT-PCR.

\section{METHODS}

CovidNudge point of care test for SARS-CoV-2

33 The platform comprises two components: the DnaCartridge and a processing unit (NudgeBox) (Figure 1).

34 The DnaCartridge $(25 \times 78 \times 85 \mathrm{~mm} ; 40 \mathrm{~g})$ is a disposable, sealed, and integrated lab-on-chip device that enables sample-to-result PCR. The DnaCartridge consists of two main parts: an amplification unit (AU) and a sample preparation unit (SPU). A swab is immediately inserted directly into the swab chamber of the SPU at the time of collection. The swab is broken leaving the swab tip and the sample within the chamber, which is then sealed. Cartridges are placed in the processing unit (NudgeBox, 28x15.5x13.5cm; 5kg), which provides the pneumatic, thermal, imaging and mechanics required to run an RT-PCR reaction outside of a

40 laboratory setting. The SPU consists of a rotatable mixing unit and circumferentially distanced chambers, containing buffers to extract and purify RNA from the swab sample, as well as a lyophilised PCR mastermix to mix with the extracted RNA (Figure 1B). The SPU mixing chamber fits on top of a motor-driven spigot in the NudgeBox, which rotates the mixing unit through each stage of sample processing before

44 filling the wells of the AU, inside which the PCR reaction takes place. Exposed surfaces of the instruments are cleaned regularly between operators with $10 \%$ bleach, followed by an isopropyl alcohol wipe to remove any residual bleach. Following the test, the single-use cartridge is disposed of following standard laboratory disposal procedures. 
medRxiv preprint doi: https://doi.org/10.1101/2020.08.13.20174193; this version posted August 15, 2020. The copyright holder for this preprint (which was not certified by peer review) is the author/funder, who has granted medRxiv a license to display the preprint in It is made available under a CC-BY-NC-ND 4.0 International license .

The AU comprises dried primers and probes uniquely spotted into 72 reaction wells providing multiplex analysis (Figure 1C, SUPPLEMENTARY METHODS). For the SARS-CoV-2 assay, the array consists of seven viral targets $(r d r p 1, r d r p 2, e \text {-gene, } n \text {-gene, } \mathrm{n} 1, \mathrm{n} 2 \text { and } \mathrm{n} 3)^{7,18,19}$ and one host gene as a positive control assay (Ribonuclease P, RNaseP). Each target has between six to nine technical replicates. The AU sits on top of an active heating and cooling plate, which drives the thermal cycling conditions for the PCR reaction. Multiple cycles of PCR are performed generating florescence data similar to conventional PCR instruments (Figure 1).

For a well to be classified as having amplified, the amplification curve should reflect the exponential growth and decay of a standard PCR reaction..$^{20} \mathrm{~A}$ test is considered valid if $\geq 3 / 6$ replicates of human RNaseP amplify, reflecting adequate mucosal sampling (see SUPPLEMENTARY METHODS). If two or fewer replicates amplify, it is assumed that sample collection was inadequate and the test labelled as invalid. We defined a positive test when $\geq 2$ replicates of at least one viral gene target amplified, otherwise a test was considered negative for SARS-CoV-2.

Clinical assessment took place at three sites in the United Kingdom: St Mary's Hospital, Imperial Healthcare NHS Trust, London (IHCT); Chelsea \& Westminster Hospital NHS Foundation Trust, London (CWFT) and the John Radcliffe Hospital, Oxford University Hospitals NHS Foundation Trust, Oxford (OUH). All participants consented to two nasopharyngeal swabs being taken. During this period the incidence of COVID-19 in the UK peaked. ${ }^{21}$

69

Paired samples collected from the same site in the same patient or staff member were tested in parallel POC and laboratory platforms, with results from CovidNudge testing reported before laboratory results were available. Smaller caliber (pediatric) swabs were used to insert into the CovidNudge cartridge, most commonly a flexible minitip FLOQswab ${ }^{\mathrm{TM}}$ (COPAN Diagnostics Inc, Italy), whilst a second parallel combined oropharyngeal and nasopharyngeal swab was collected using a standard swabs and placed in viral 
medRxiv preprint doi: https://doi.org/10.1101/2020.08.13.20174193; this version posted August 15, 2020. The copyright holder for this preprint (which was not certified by peer review) is the author/funder, who has granted medRxiv a license to display the preprint in It is made available under a CC-BY-NC-ND 4.0 International license.

transport medium for processing in a central laboratory as per local protocols (SUPPLEMENTARY

METHODS).

Laboratory samples were processed at United Kingdom Accreditation Service (UKAS) laboratories.

Samples collected at CWFT and IHCT were processed at the North West London Pathology Laboratory

(NWLP, Charing Cross Hospital). Those collected OUH were processed at the John Radcliffe Hospital.

Assessment took place at the peak of the epidemic in the UK and performance was compared to the

Centralized laboratory testing and POC testing were performed by separate staff members. Staff performing centralized laboratory testing were blinded to the POC test results and vice-versa.

Samples were collected from three groups: i) Group 1 - self-referred, non-hospitalized healthcare workers or their family members with suspected COVID-19 (10th April to 12th may) at two sites (ICHT, OUH);

ii) Group 2 - patients admitted to emergency department with suspected COVID-19 at one site (ICHT). Suspected COVID-19 was defined as a patient presenting with any of the following: temperature $\geq 37.8^{\circ} \mathrm{C}$; clinical evidence of pneumonia (e.g. cough, dyspnoea); hypoxia or an abnormal chest radiograph. Hospital staff were encouraged to self-refer and were eligible for testing if they self-reported any of the following symptoms: Fever $\geq 37.8^{\circ} \mathrm{C}$ or subjective fever, fatigue or malaise, cough and/or sputum production, muscle aches, headache, sore throat, profound loss of smell and taste. iii) Group 3 - consecutive hospital inpatient admissions with or without suspected COVID-19 from 12th to the 18th May at one site (CWFT).

97 Participants in Group 2 were consented as part of the communicable disease research tissue bank (ethical approval ref 15/SC/0089). Following derogation from the Medicines and Healthcare Regulatory Agency

99 (MHRA) evaluation within staff testing at all three sites was performed as a service evaluation in parallel with routine SARS-CoV-2 RT-PCR testing. Verbal or written consent for an additional swab was obtained from each participant and results from POC testing were not fed back to the individual participants. 
medRxiv preprint doi: https://doi.org/10.1101/2020.08.13.20174193; this version posted August 15, 2020. The copyright holder for this preprint (which was not certified by peer review) is the author/funder, who has granted medRxiv a license to display the preprint in It is made available under a CC-BY-NC-ND 4.0 International license .

102 Analysis of Group 3 was conducted as a service evaluation approved by the Point of Care Committee

103 at Chelsea \& Westminster NHS Foundation Trust and results were used to inform patient care.

104

105

Statistical Analyses

106 Data analysis was performed using $\mathrm{R}$ version $4.0^{22}$ using the epiR ${ }^{23}$ and the pheatmap ${ }^{24}$ packages. The

107 primary analysis was conducted on paired samples collected on the same day. A secondary analysis was

108 performed by sub-group, including by sample month, study site, location of sampling and comparator

109 platform. Samples testing invalid on the CovidNudge platform were not included in the primary sensitivity

110 analysis and were analysed separately. One batch of eight samples collected on one day at one site were

111 excluded due to laboratory assay failure.

112

113 Role of the funding source

114 Institutional support was provided in part by the NIHR Imperial Biomedical Research Centre and NIHR

115 Biomedical Research Centre, Oxford. DnaNudge Ltd. supplied the test cartridges and NudgeBox 116 processing units. The corresponding author had full access to all the data in the study and had final 117 responsibility for the decision to submit for publication.

\section{RESULTS}

119 In vitro analysis with spiked SARS-CoV-2 RNA (SUPPLEMENTARY METHODS) found the lower

120 limit of detection (LLOD) to be 5 viral RNA copies/ul for the $n 3$ assay, 10 viral RNA copies/ul for $n 1, n 2$

121 and $E$ assays whilst LLOD for $r d r p 1, r d r p 2$ and $n 1$ targets was 50 viral RNA copies/ul (Supplementary Table

122 1Error! Reference source not found.). When the cartridge was spiked with whole virus particles into the

123 lysis buffer chamber, the lower limit of detection was $1 \times 10^{4}$ viral particles/sample for the $n 1, n 2$ and $n 3$ 124 targets (Supplementary Table 2). ${ }^{5}$

125 
medRxiv preprint doi: https://doi.org/10.1101/2020.08.13.20174193; this version posted August 15, 2020. The copyright holder for this preprint (which was not certified by peer review) is the author/funder, who has granted medRxiv a license to display the preprint in It is made available under a CC-BY-NC-ND 4.0 International license .

126 Clinical assessment was performed over a six-week period between the $2^{\text {nd }}$ April and $18^{\text {th }}$ May 2020. A

127 total of 449 same-day samples were collected. Complete clinical data, paired with laboratory tests were

128 available for 386 , which were included in the primary analysis. The median age of study participants was

12946 years (interquartile range 31 to 66 years) and $68 \%$ were female. A total of $280 / 386(73 \%)$ of samples

130 were collected from Group 1, 15/386 (4\%) from Group 2 and 91/386 (23\%) from Group 3 (

\section{Figure 2).}

132

133 The overall prevalence of laboratory positive tests was $18 \%(71 / 386)$ with the highest prevalence being

134 observed in patients attending the emergency department with suspected COVID-19 (33\%; 95\% CI 12 -

$13562 \%)$ and in samples collected in the month of April 2020 (25\%; 95\%CI 20-31\%). The prevalence was

136 lower in staff testing (group 1;23\% [18-28\%]) and inpatient screening (group 3; 3\% [1-9\%]). In the primary

137 analysis, the overall sensitivity of the POC test compared with a laboratory-based testing was 94\% (95\%

138 Confidence interval 86-98\%) with a specificity of 100\% (99-100\%; positive predictive value [PPV] 100\%

139 [94-100\%]; negative predictive value [NPV] 99\% [97-100\%]) (Table ). The platform performed equally well

140 when compared against a range of laboratory-based platforms and in different clinical settings

141 (Supplementary Table 3).

142

143 A subset of samples collected from symptomatic staff testing in one site $(102 / 386 ; 26 \%)$ were run on three

144 RT-PCR platforms (the CovidNudge point-of care test, the Public Health England RT-PCR assay targeting

$145 r d r p$ and the ThermoFisher assay targeting orf1ab, the spike $[\mathrm{S}]$ gene and the nucleocapsid $[\mathrm{N}]$ gene -

146 SUPPLEMENTARY METHODS). Of these, 78/102 (76\%) tested negative on all three platforms. Of

147 samples testing positive with at least one assay (24/102 [24\%]), a total of 22/24 (92\%) were congruent

148 across all three assays (Supplementary Figure 2).

149

150 The viral targets amplified varied markedly between individuals, with the most common amplified targets

151 being the $n 3, e$ - and $n 1$ targets (Error! Reference source not found.Error! Reference source not found.). 
medRxiv preprint doi: https://doi.org/10.1101/2020.08.13.20174193; this version posted August 15, 2020. The copyright holder for this preprint (which was not certified by peer review) is the author/funder, who has granted medRxiv a license to display the preprint in It is made available under a CC-BY-NC-ND 4.0 International license .

153 Twenty-four samples processed on the point of care platform were reported as invalid due to failure to

154 amplify human $R N a s e P$ in the point of care test, of which 22 had corresponding results from a laboratory specimen; of these, $16 / 22(73 \%)$ tested negative.

\section{DISCUSSION}

157 In a diagnostic accuracy study conducted during the first peak of the UK COVID-19 pandemic, we have

158 demonstrated that a lab-free point-of-care diagnostic test for SARS-CoV-2 had 94\% sensitivity and 100\%

159 specificity when compared with standard laboratory-based RT-PCR. The key advantage of the CovidNudge

160 platform is as a fully-automated direct sample-to-answer platform, removing the need for the laboratory

161 infrastructure required for traditional RT-PCR. The run-time (under 90 minutes) is more rapid than other

162 laboratory based diagnostic platforms. ${ }^{9}, 13$ The data suggest that the CovidNudge platform has comparable

163 or greater sensitivity and specificity than other rapid assays using dry swabs, ${ }^{15,25}$ and this will require head

164 to head evaluation in future. In contrast to other rapid tests which still require viral transport medium and

165 a simple sample transfer step, ${ }^{15}$ swabs are loaded directly into a fully sealed cartridge which allows safe

166 testing outside of laboratory, potentially including primary care and community settings. We acknowledge

167 that accuracy and a rapid run-time represents only some aspects of real-world POC test deployment.

168 Prospective effectiveness studies are required to assess operational challenges, including access to

169 equipment, impact on clinical decision making, cost effectiveness and equity of access.

171 The cartridge design allows the inclusion of multiple assays. One of these, human RNaseP control, is able

172 to help ensure sample adequacy, a major challenge with many existing assays which cannot distinguish a

173 true negative from an insufficient sample. In our study, $73 \%$ of samples reported as invalid on the POC

174 platform (due to negative control) were reported as negative on laboratory assays lacking a sample adequacy

175 control, some of which may have been false negatives. Reporting invalid results rapidly allows clinical

176 decision makers the opportunity to repeat a test where the information is needed for clinical management. 
medRxiv preprint doi: https://doi.org/10.1101/2020.08.13.20174193; this version posted August 15, 2020. The copyright holder for this preprint (which was not certified by peer review) is the author/funder, who has granted medRxiv a license to display the preprint in It is made available under a CC-BY-NC-ND 4.0 International license .

178 At the onset of the epidemic, the inclusion of several validated assays for different viral targets was expected

179 to improve sensitivity. Surprisingly, one target in the $\mathrm{N}$ gene (n3) was positive in all positive cases, whereas

$180 r d r p 1$ and $r d p 2$ targets performed less well, consistent with previous reports. ${ }^{26}$ The design of the cartridge

181 (Figure 1C), with each assay distributed across the analytical unit, means this difference is more likely due

182 to biological differences in assay performance, than technical performance of the cartridge. Future

183 adaptation will be to replace redundant assays with targets for respiratory syndromic screening (e.g.

184 influenza, RSV) in anticipation of the diagnostic challenges on entering annual influenza season. Further

185 work is required to understand how the algorithm relates to standard PCR measurements, such as the cycle

186 threshold $\left(\mathrm{C}_{\mathrm{t}}\right)$ value, as well as virus viability, viral load, transmissability, and the performance of $\operatorname{sgRNA}$

187 targets in the cartridge to assess infectivity. 5,27

189 We acknowledge the limitations of our study. The clinical assessment took place during a period of 190 exceptionally heavy demand on clinical and laboratory services in the UK. It was not possible to use a single 191 laboratory platform for comparison as the supply of reagents was inconsistent and unpredictable. Cross192 platform comparison of two laboratory platforms was performed in a subset of samples. Given the POC assay had comparable performance against a range of other commercial platforms run in different labs, it is reasonable to expect that similar performance would be observed in different clinical settings. Following recent CE marking to allow testing outside of hospitals, and NHS procurement, a standard process for the roll-out is being developed by the NHS taking into account this issue. Nevertheless, we advocate for local assessment to compare performance against existing local standards of care when the device is first deployed in a new setting. Falling incidence of infection during the period of study meant it was not

199 possible to validate the test with a larger number of positive samples, however, the high specificity in a

200 cohort with low background prevalence is reassuring given the risks of incorrectly placing a patient without

201 infection into a ward designated for SARS-CoV-2 infected patients.

203 Centralised testing with RT-PCR has the advantage of high throughput processing that cannot be achieved

204 by the CovidNudge platform at the current time. As each processing unit (NudgeBox) can process one cartridge at a time, the assay has relatively low throughput and multiple processing units maybe required 
medRxiv preprint doi: https://doi.org/10.1101/2020.08.13.20174193; this version posted August 15, 2020. The copyright holder for this preprint (which was not certified by peer review) is the author/funder, who has granted medRxiv a license to display the preprint in It is made available under a CC-BY-NC-ND 4.0 International license .

206 depending on the clinical setting. However, judicious application of point-of-care tests could relieve the

207 burden on central laboratories and increase overall testing capacity, complementing existing approaches.

208 The platform has a role in testing strategies where results can impact real-time decision making such as 209 prescribing specific SARS-CoV-2 therapy (e.g. remdesivir or dexamethasone), triaging unscheduled

210 admissions (e.g. to emergency departments and maternity units) and screening elective admissions or staff

211 (e.g. prior to procedures such as surgery or chemotherapy). In addition, each device is linked to a secure

212 cloud-based database via $\mathrm{WiFi}$, allowing results to be delivered directly to clinical information systems. The

213 potential exists to link to patient smartphones applications and/or test and trace facilities, although further

214 work on acceptability, privacy and information governance are planned for future work. In principle, the

215 platform is well suited to testing in primary care and community settings (e.g. long term care facilities or

216 contact tracing programs) with potential for use in non-healthcare settings (e.g. prisons, transport hubs or

217 offices). However, further studies of real-world effectiveness in non-clinical settings would be required

218 prior to widespread deployment.

220 Enhanced testing forms a central pillar of global efforts to control SARS-CoV-2. ${ }^{27}$ We have described the

221 first report of the development and clinical assessment of highly sensitive and specific rapid point-of-care

222 platform for the detection of SARS-CoV-2, validated in frontline clinical settings during the first peak of 223 the COVID-19 pandemic. The device is already in use in clinical settings in the UK and is one component

224 of the testing strategy which is required to contain the COVID19 pandemic. ${ }^{28}$ 
medRxiv preprint doi: https://doi.org/10.1101/2020.08.13.20174193; this version posted August 15, 2020. The copyright holder for this preprint (which was not certified by peer review) is the author/funder, who has granted medRxiv a license to display the preprint in It is made available under a CC-BY-NC-ND 4.0 International license .

\section{REFERENCES}

1 Coronaviridae Study Group of the International Committee on Taxonomy of Viruses. The species Severe acute respiratory syndrome-related coronavirus: classifying 2019-nCoV and naming it SARS-CoV-2. Nat Microbiol 2020; 5: 536-44.

2 Johns Hopinks University. COVID-19 Map - Johns Hopkins Coronavirus Resource Center. https://coronavirus.jhu.edu/map.html (accessed May 31, 2020).

3 He X, Lau EH, Wu P, et al. Temporal dynamics in viral shedding and transmissibility of COVID19. Nat Med 2020. DOI:10.1038/s41591-020-0869-5.

4 Wikramaratna P, Paton RS, Ghafari M, Lourenço J. Estimating false-negative detection rate of SARS-CoV-2 by RT-PCR. medRxiv 2020; : 2020.04.05.20053355.

5 Wölfel R, Corman VM, Guggemos W, et al. Virological assessment of hospitalized patients with COVID-2019. Nature 2020. DOI:10.1038/s41586-020-2196-x.

6 Zhou P, Yang X-L, Wang X-G, et al. A pneumonia outbreak associated with a new coronavirus of probable bat origin. Nature 2020; 579: 270-3.

7 Corman VM, Landt O, Kaiser M, et al. Detection of 2019 novel coronavirus (2019-nCoV) by realtime RT-PCR. Eurosurveillance 2020; 25: 2000045.

8 Arevalo-Rodriguez I, Buitrago-Garcia D, Simancas-Racines D, et al. FALSE-NEGATIVE RESULTS OF INITIAL RT-PCR ASSAYS FOR COVID-19: A SYSTEMATIC REVIEW. medRxiv 2020; : 2020.04.16.20066787.

9 Green K, Graziadio S, Turner P, Fanshawe T, Allen J, Oxford COVID-19 Evidence Service Team. Oxford COVID-19 Evidence Service: Molecular and antibody point-of-care tests to support the screening, diagnosis and monitoring of COVID-19. Oxford COVID-19 Evid. Serv. Team. 2020. https://www.cebm.net/wp-content/uploads/2020/04/POCT-Covid19.pdf (accessed June 6, 2020).

10 Public Health England. COVID-19: guidance for taking swab samples - GOV.UK. 2020. https://www.gov.uk/government/publications/covid-19-guidance-for-taking-swab-samples (accessed May 31, 2020).

11 Tu YP, Jennings R, Hart B, et al. Swabs Collected by Patients or Health Care Workers for SARSCoV-2 Testing. N Engl J Med 2020; : 1-3.

12 Raftery P, Condell O, Wasunna C, et al. Establishing Ebola Virus Disease (EVD) diagnostics using GeneXpert technology at a mobile laboratory in Liberia: Impact on outbreak response, case management and laboratory systems strengthening. PLoS Negl Trop Dis 2018; 12: e0006135.

13 WHO. COVID 19 Public Health Emergency of International Concern (PHEIC) Global research and innovation forum: towards a research roadmap. 2020.

14 Hanson KE, Azar MM, Banerjee R, et al. Molecular testing for acute respiratory tract infections: clinical and diagnostic recommendations from the IDSA's Diagnostics Committee. Clin Infect Dis 2020; published online May 5. DOI:10.1093/cid/ciaa508.

15 Assennato SM, Ritchie A V, Nadala C, et al. Performance evaluation of the point-of-care SAMBA II SARS-CoV-2 Test for detection of SARS-CoV-2. medRxiv 2020; : 2020.05.24.20100990.

16 Toumazou C, Lowe SB, Green SW, et al. Method and Apparatus for Analysing a Biological Sample: Patent No: US 10,093,965 B2. 2018. https://patentimages.storage.googleapis.com/e6/c2/36/e1 fc24e6588746/US10093965.pdf (accessed May 28, 2020).

17 DNANudge ltd. https://www.dnanudge.com/ (accessed May 28, 2020).

18 Centers for Disease Control and Prevention (CDC). 2019-Novel Coronavirus (2019-nCoV) Realtime rRT-PCR Panel Primers and Probes. 2020 https://www.cdc.gov/coronavirus/2019ncov/downloads/rt-pcr-panel-primer-probes.pdf (accessed May 29, 2020).

19 WHO. Molecular assays to diagnose COVID-19: Summary table of available protocols. 2020 https://www.who.int/docs/defaultsource/coronaviruse/whoinhouseassays.pdf?sfvrsn=de3a76aa_2\&download=true (accessed May 
medRxiv preprint doi: https://doi.org/10.1101/2020.08.13.20174193; this version posted August 15, 2020. The copyright holder for this preprint (which was not certified by peer review) is the author/funder, who has granted medRxiv a license to display the preprint in It is made available under a CC-BY-NC-ND 4.0 International license

29, 2020).

20 Spiess AN, Feig C, Ritz C. Highly accurate sigmoidal fitting of real-time PCR data by introducing a parameter for asymmetry. BMC Bioinformatics 2008; 9: 1-12.

21 Public Health England. Coronavirus (COVID-19) in the UK. https: / / coronavirus.data.gov.uk/?_ga=2.73146385.388369843.15907913291796103055.1577532895 (accessed May 29, 2020).

22 The R Core team. R: A Language and Environment for Statistical Computing. 2013. http://www.r-project.org/.

23 Mark Stevenson. Package 'epiR' Version 1.0-14. 2020. https://cran.r-

project.org/web/packages/epiR/epiR.pdf (accessed April 30, 2020).

24 Kolde R. Package 'pheatmap'. CRAN. 2019. https://cran.rproject.org/web/packages/pheatmap/pheatmap.pdf (accessed June 7, 2020).

25 Basu A, Zinger T, Inglima K, et al. Performance of Abbott ID NOW COVID-19 rapid nucleic acid amplification test in nasopharyngeal swabs transported in viral media and dry nasal swabs, in a New York City academic institution. J Clin Microbiol 2020; published online May 29. DOI:10.1128/JCM.01136-20.

26 Colton $\mathrm{H}$, Ankcorn M, Yavuz M, et al. Improved sensitivity using a dual target, $\mathrm{E}$ and RdRp assay for the diagnosis of SARS-CoV-2 infection: Experience at a large NHS Foundation Trust in the UK. J Infect 2020; published online May 28. DOI:10.1016/j.jinf.2020.05.061.

27 WHO. Critical preparedness, readiness and response actions for COVID-19: WHO/2019nCoV/Community_Actions/2020.3. 2020. https://www.who.int/publications-detail/criticalpreparedness-readiness-and-response-actions-for-covid-19 (accessed May 30, 2020).

28 Department of Health and Social Care. Coronavirus (COVID-19) Scaling up our testing programmes Department of Health and Social Care. 2020 https://assets.publishing.service.gov.uk/government/uploads/system/uploads/attachment_data/ file/878121/coronavirus-covid-19-testing-strategy.pdf.

29 NHS England. Guidance and standard operating procedure COVID-19 virus testing in NHS laboratories. https://www.england.nhs.uk/coronavirus/wp-

content/uploads/sites/52/2020/03/guidance-and-sop-covid-19-virus-testing-in-nhs-laboratoriesv1.pdf (accessed May 28, 2020). 
medRxiv preprint doi: https://doi.org/10.1101/2020.08.13.20174193; this version posted August 15, 2020. The copyright holder for this preprint (which was not certified by peer review) is the author/funder, who has granted medRxiv a license to display the preprint in It is made available under a CC-BY-NC-ND 4.0 International license .

\section{ACKNOWLEDGEMENTS}

The authors wish to acknowledge the contribution of participants and the staff of Imperial College NHS Trust, Oxford University NHS Trust, North West London Pathology and Imperial College Molecular Diagnostic Unit. The work was supported by the Biomedical Research Centre of Imperial College NHS Trust. M.M.G. is supported in part by the NIHR Imperial Biomedical Research Centre. GC is an NIHR Research Professor and Investigator within the NIHR London In-vitro Diagnostic Collaborative. Part of this work was supported by the National Institute for Health Research Health Protection Research Unit (NIHR HPRU) in Healthcare Associated Infections and Antimicrobial Resistance at Oxford University in partnership with Public Health England (PHE) [grant HPRU-2012-10041] and the NIHR Biomedical Research Centre, Oxford. The views expressed in this publication are those of the authors and not necessarily those of the NHS, the National Institute for Health Research, the Department of Health or Public Health England.

\section{AUTHOR CONTRIBUTIONS}

Assay design and development was performed by CT (genetics and bioengineering design), RS (assay development and molecular biology), MS (platform technology and cartridge design), MK (genetics and microbiology), TH, SDM, FL, JB and AO.

Laboratory development was supported by WB, GPT and GC.

Clinical evaluation was led by MMG, JB-N, BF, RK, GD, LSPM, NM, KJ,DC, GC and AB.

NHS laboratory testing was undertaken by KS, PR, DM DC and KJ.

Analysis was performed by MMG, CT, GC, RS and MS.

The first draft of manuscript was written by MMG and GC. All authors reviewed and approved the final manuscript.

CT is the co-inventor of the DnaNudge CovidNudge system.

\section{COMPETING INTEREST DECLERATION}

CT, RS, MS, CI, MK, TH, SDM, FL, JB and AO are employees of DnaNudge. CT is named on the patent for method and apparatus for analyzing biological specimens on the DnaNudge platform (US Patent No: US 10,093,965 B216. LSPM has consulted for bioMerieux (2013-2020), DNAelectronics (2015), Dairy Crest (2017-2018), Pfizer (2018-2020), and Umovis Lab (2020), received speaker fees from Profile Pharma (2018), received research grants from the National Institute for Health Research (2013-2019), Leo Pharma (2016), and CW + Charity (2018-2019), and received educational support from Eumedica (2016-2017). NM has received speaker fees from Beyer (2016) and Pfizer (2019) and received educational support from Eumedica (2016) and Baxter (2017). All other authors have no conflicts of interest to declare. 
medRxiv preprint doi: https://doi.org/10.1101/2020.08.13.20174193; this version posted August 15, 2020. The copyright holder for this preprint (which was not certified by peer review) is the author/funder, who has granted medRxiv a license to display the preprint in perpetuity.

It is made available under a CC-BY-NC-ND 4.0 International license .

\section{FIGURE LEGENDS}

Figure 1 CovidNudge point of care diagnostic for SARS-CoV-2. (A) Schematic of the work-flow. A swab is collected and loaded directly into the DnaCartridge, comprising a sample preparation unit (SPU) and amplification unit (AU). The DnaCartridge is placed into a slot on the lower half of the nudge box, where its SPU mixing chamber fits on top of a motordriven spigot and the $A U$ sits on top of an active heating and cooling plate. The spigot also connects the DnaCartridge mixing chamber to the pneumatic subsystem. By sliding the upper half to close the NudgeBox, the imaging system aligns on top of the DnaCartridge AU. The upper half also consists of a thermal subsystem which is thermally connected to a mesh plate sitting on top of the $A U$, which drives the PCR reaction. Data are delivered by WiFi to a cloud-based analysis platform and results are delivered directly to a patients electronic health record. (B) Schematic of sample preparation unit (SPU). The test starts with moving the lysis buffer to the swab chamber. The lysis kills and deactivates the (viral) sample and releases the sample $\mathrm{RN} A$. Silica frit filters are mounted on to the port in the mixing chamber which can capture RNA molecules. The lysis buffer moves from the swab chamber to the mixing chamber and the extracted $\mathrm{RN} A$ strands bind to the silica frit filter. In the next step, wash buffer is passed through the mixing chamber and any debris is removed. In the third step, the elution buffer releases the $\mathrm{RN} A$ strands from the frit. The elution buffer containing the sample $\mathrm{RN} A$ is used to reconstitute the lyophilised $\mathrm{RT}$ master mix. In the last step of sample preparation, the mixing chamber turns toward the AU filling port of the SPU to fill the AU. (C) Schematic of the amplification unit (AU). The wells are formed by sealing a mesh membrane to the bottom of the chassis, each less than 1.8uL in volume. Primers and probes for each assay are spotted in nanoliters into the wells, and air dried. To provide redundancy and increase reliability, they are distributed into several wells. The spotting pattern is used by the algorithm to analyse the PCR amplification signals. Each well is represented by a circle coloured according to its assay deposition. Crossed wells indicate target replicated that have amplified in a specific reaction.

Figure 2 Profile of clinical study. Tests were considered valid if $\geq 3 / 6$ replicates of $R$ NaseP amplified. Suspected COVID19 in the emergency department was defined as a patient presenting with any of the following: temperature $=>37.8^{\circ} \mathrm{C}$; clinical evidence of pneumonia (e.g. cough, dyspnoea); hypoxia or an abnormal chest radiograph. Healthcare workers were eligible for testing if they self-reported any of the following symptoms: Fever $=>37.8 \mathrm{C}$ or subjective fever, fatigue or malaise, cough and/ or sputum production, muscle aches, headache, sore throat, profound loss of smell and taste.

Figure 3 - Heat map illustrating SARS-CoV-2 gene targets amplified in the CovidNudge point of care test. Rows correspond to samples and columns correspond to target genes spotted on the amplification unit of the CovidNudge cartridge. Illustrated are samples testing positive on the point of care platform, corresponding to samples where $\geq 2$ replicates of at least one viral gene target amplified with $\geq 3$ buman RNaseP control replicates amplifying. Displayed are mean c values for each gene target amplified, corresponding to the inflection point of the sigmoid reaction curve, where the PCR reaction stops its exponential growth phase and begins its exponential decay phase.20 The c values are scaled using min-max normalisation, with a bigher score corresponding to lower cycle number. Targets not amplified are displayed in grey. Clustering by Euclidean distance.

Table 1 Clinical assessment of point of care testing. Presented are paired samples collected contemporaneously. Samples testing invalid on the point of care test are not included $(n=23)$. Results are presented according to location of testing, context of testing, laboratory platform and time period of testing. All samples were collected by nasopharyngeal swabs. 
10. TABLES

Table 1 - Clinical assessment of point of care testing compared with laboratory RT-PCR. Presented are paired samples collected contemporaneously. Samples testing invalid on the point of care test are not included (n=24). Results are presented according to location of testing, context of testing, laboratory platform and time period of testing. All samples were collected by nasopharyngeal swabs.

\begin{tabular}{|c|c|c|c|c|c|c|c|c|c|c|c|}
\hline & & \multicolumn{2}{|c|}{ Laboratory Testing } & \multicolumn{2}{|c|}{ Point of Care Testing } & & & & & & \\
\hline & Tested (n) & Positive & Negative & Positive & Negative & Prevalence & $\begin{array}{c}\text { Sensitivity } \\
(95 \% \mathrm{CI})\end{array}$ & $\begin{array}{c}\text { Specificity } \\
(95 \% \mathrm{CI})\end{array}$ & $\begin{array}{l}\text { Positive } \\
\text { Predictive } \\
\text { Value } \\
(95 \% \mathrm{CI})\end{array}$ & $\begin{array}{c}\text { Negative } \\
\text { Predictive } \\
\text { Value } \\
(95 \% \mathrm{CI})\end{array}$ & $\begin{array}{c}\text { Negative } \\
\text { Likelihood } \\
\text { Ratio } \\
(\mathbf{9 5 \%} \text { CI }\end{array}$ \\
\hline Total & 386 & 71 & 315 & 67 & 319 & $\begin{array}{c}0.18(0.15 \\
0.23)\end{array}$ & $\begin{array}{c}0.94(0.86 \\
0.98)\end{array}$ & $\begin{array}{c}1.00(0.99 \\
1.00)\end{array}$ & $\begin{array}{c}1.00(0.94 \\
1.00)\end{array}$ & $\begin{array}{c}0.99(0.97 \\
1.00)\end{array}$ & $\begin{array}{c}0.06(0.02 \\
0.15)\end{array}$ \\
\hline \multicolumn{12}{|l|}{ Sample context } \\
\hline Symptomatic Staff Testing & 280 & 61 & 209 & 57 & 213 & $\begin{array}{c}0.23(0.18 \\
0.28)\end{array}$ & $\begin{array}{c}0.93(0.84 \\
0.98)\end{array}$ & $\begin{array}{c}1.00(0.98 \\
1.00)\end{array}$ & $\begin{array}{c}1.00(0.94 \\
1.00)\end{array}$ & $\begin{array}{c}0.98(0.95 \\
0.99)\end{array}$ & $\begin{array}{c}0.07(0.03 \\
0.17)\end{array}$ \\
\hline Emergency Department & 15 & 5 & 10 & 5 & 10 & $\begin{array}{c}0.33(0.12 \\
0.62)\end{array}$ & $\begin{array}{c}1.00(0.48 \\
1.00)\end{array}$ & $\begin{array}{c}1.00(0.69 \\
1.00)\end{array}$ & $\begin{array}{c}1.00(0.48 \\
1.00)\end{array}$ & $\begin{array}{c}1.00(0.69 \\
1.00)\end{array}$ & $\begin{array}{c}0.00(0.00 \\
\mathrm{NaN})\end{array}$ \\
\hline All Hospital admissions & 91 & 3 & 88 & 3 & 88 & $\begin{array}{c}0.03(0.01 \\
0.09)\end{array}$ & $\begin{array}{c}1.00(0.29 \\
1.00)\end{array}$ & $\begin{array}{c}1.00(0.96 \\
1.00)\end{array}$ & $\begin{array}{c}1.00(0.29 \\
1.00)\end{array}$ & $\begin{array}{c}1.00(0.96 \\
1.00))\end{array}$ & $\begin{array}{c}0.00(0.00 \\
\mathrm{NaN})\end{array}$ \\
\hline \multicolumn{12}{|l|}{ Sample period } \\
\hline April 2020 & 272 & 68 & 204 & 64 & 208 & $\begin{array}{c}0.25(0.20 \\
0.31)\end{array}$ & $\begin{array}{c}0.94(0.86 \\
0.98)\end{array}$ & $\begin{array}{c}1.00(0.98 \\
1.00)\end{array}$ & $\begin{array}{c}1.00(0.94 \\
1.00)\end{array}$ & $\begin{array}{c}0.98(0.95 \\
0.99)\end{array}$ & $\begin{array}{c}0.06(0.02 \\
0.16)\end{array}$ \\
\hline May 2020 & 114 & 3 & 111 & 3 & 111 & $\begin{array}{c}0.03(0.01 \\
0.07)\end{array}$ & $\begin{array}{c}1.00(0.29 \\
1.00)\end{array}$ & $\begin{array}{c}1.00(0.97 \\
1.00)\end{array}$ & $\begin{array}{c}1.00(0.29 \\
1.00)\end{array}$ & $\begin{array}{c}1.00(0.97 \\
1.00)\end{array}$ & $\begin{array}{c}0.00(0.00, \\
\mathrm{NaN})\end{array}$ \\
\hline
\end{tabular}


medRxiv preprint doi: https://doi.org/10.1101/2020.08.13.20174193; this version posted August 15, 2020. The copyright holder for this preprint (which was not certified by peer review) is the author/funder, who has granted medRxiv a license to display the preprint in perpetuity.

It is made available under a CC-BY-NC-ND 4.0 International license.

\section{FIGURES}

A

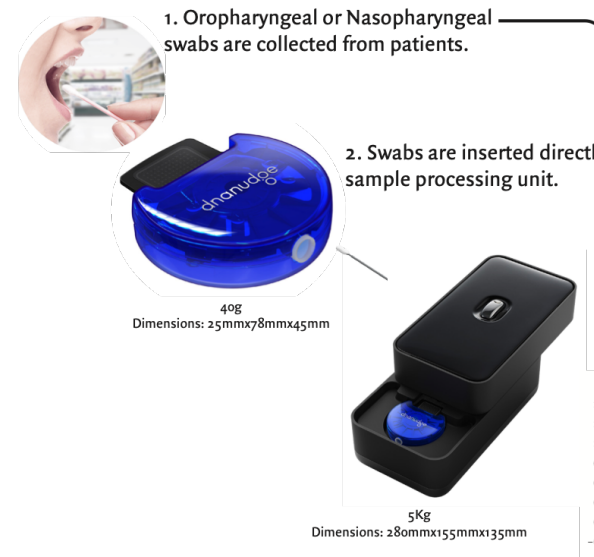

Time to result: 60 to 90 minutes.

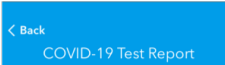

3. The DnaCartridge barcode is scanned with the operator Capsule and placed into the NudgeBox.

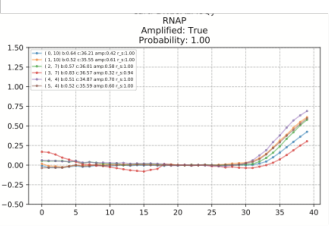

4. A real time PCR reaction takes place within the amplification unit.

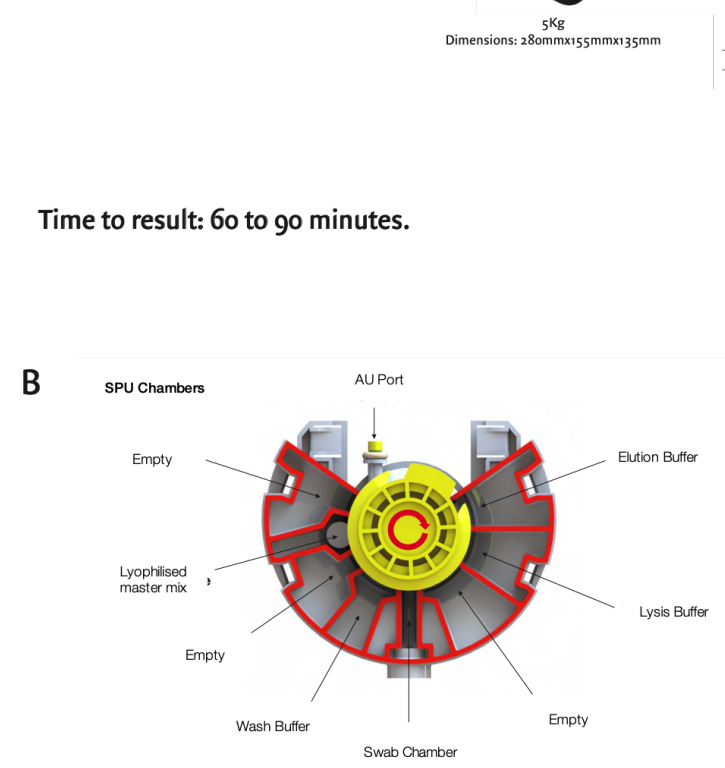

C

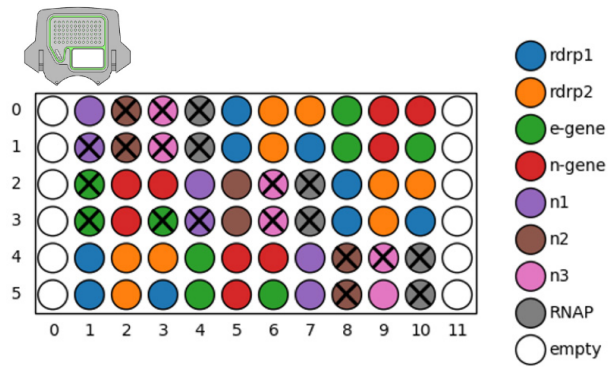

Figure 1 CovidNudge point of care diagnostic for SARS-CoV-2. (A) Schematic of the work-flow. A swab is collected and loaded directly into sealed cartridge. The DnaCartridge is placed into a slot on the lower balf of the nudge box, where its SPU mixing chamber fits on top of a motor-driven spigot and the AU sits on top of an active heating and cooling plate. The spigot also connects the DnaCartridge mixing chamber to the pneumatic subsystem. By sliding the upper half to close the NudgeBox, the imaging system aligns on top of the DnaCartridge AU. The upper half also consists of a thermal subsystem which is thermally connected to a mesh plate sitting on top of the $A U$, which drives the PCR reaction. Data are delivered by WiFi to a cloudbased analysis platform and results are delivered directly to a patient's electronic health record. (B) Schematic of sample preparation unit. The test starts with moving the lysis buffer to the swab chamber. The lysis kills and deactivates the (viral) sample and releases the sample RNA. Silica frit filters are mounted on to the port in the mixing chamber which can capture RNA molecules. The lysis buffer moves from the swab chamber to the mixing chamber and the extracted RNA strands bind to the silica frit filter. In the next step, wash buffer is passed through the mixing chamber and any debris is removed. In the third step, the elution buffer releases the RNA strands from the frit. The elution buffer containing the sample RNA is used to reconstitute the byophilised RT master mix. In the last step of sample preparation, mixing chamber turns toward the AU filling port of the SPU to fill the AU. (C) Schematic of the amplification unit. The wells are formed by sealing a mesh membrane to the bottom of the chassis, each less than 1.8uL in volume. Primers and probes for each assay are spotted in nanoliters into the wells, and air dried. To provide redundancy and increase reliability, they are distributed into several wells. The spotting pattern is used by the algorithm to analyse the PCR amplification signals. Each well is represented by a circle coloured according to its assay deposition. Crossed wells indicate target replicated that have amplified in a specific reaction. 
medRxiv preprint doi: https://doi.org/10.1101/2020.08.13.20174193; this version posted August 15, 2020. The copyright holder for this preprint (which was not certified by peer review) is the author/funder, who has granted medRxiv a license to display the preprint in perpetuity.

It is made available under a CC-BY-NC-ND 4.0 International license

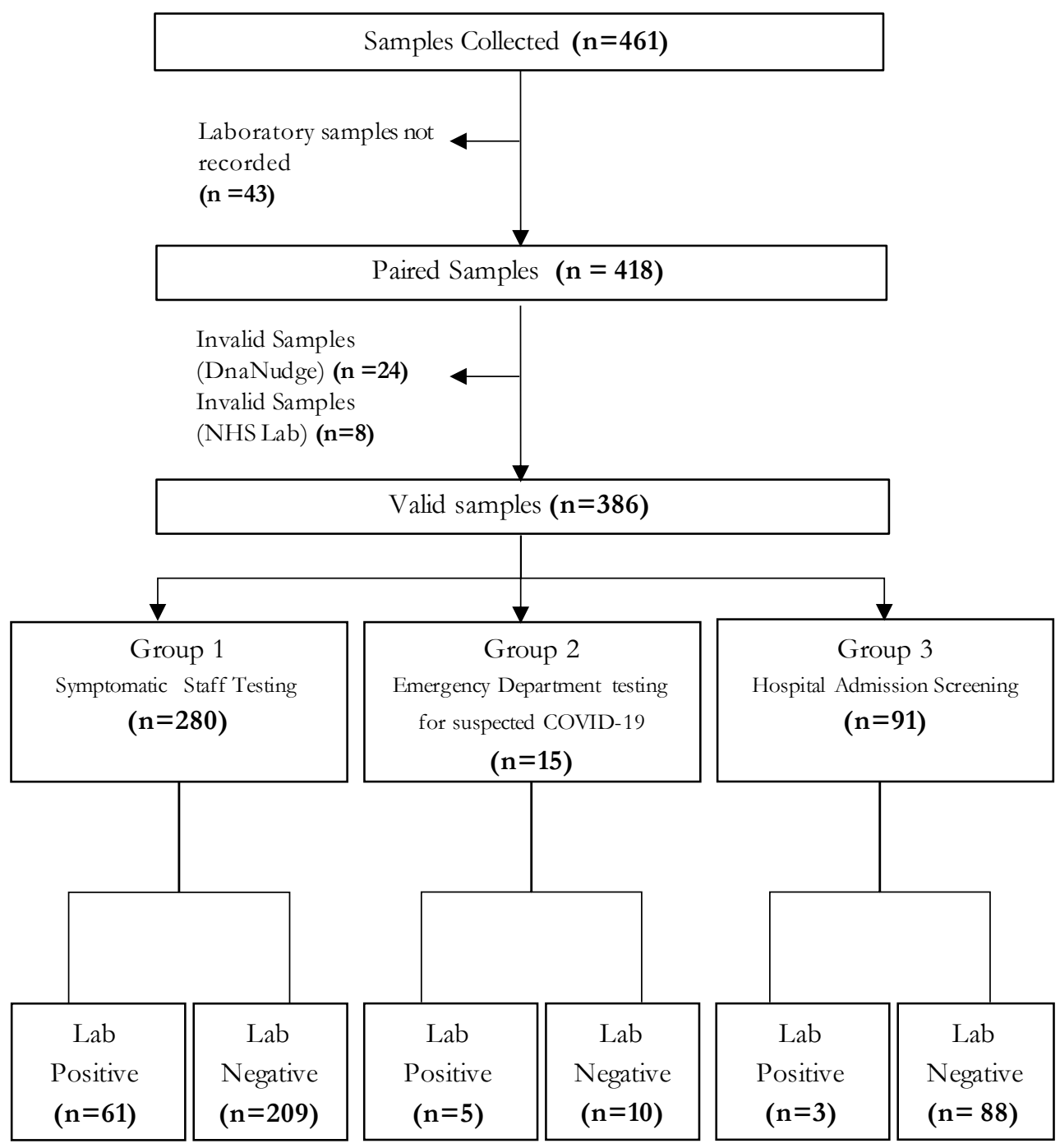

Figure 2 Profile of clinical study. Tests were considered valid if $\geq 3 / 6$ replicates of RNaseP amplified. Suspected COVID-19 in the emergency department was defined as a patient presenting with any of the following: temperature $=>37.8^{\circ} \mathrm{C}$; clinical evidence of pneumonia (e.g. congh, dyspnoea); hypoxia or an abnormal chest radiograph. Healthcare workers were eligible for testing if they self-reported any of the following symptoms: Fever $=>37.8$ $C$ or subjective fever, fatigue or malaise, cough and/ or sputum production, muscle aches, headache, sore throat, profound loss of smell and taste 
medRxiv preprint doi: https://doi.org/10.1101/2020.08.13.20174193; this version posted August 15, 2020. The copyright holder for this preprint (which was not certified by peer review) is the author/funder, who has granted medRxiv a license to display the preprint in perpetuity.

It is made available under a CC-BY-NC-ND 4.0 International license

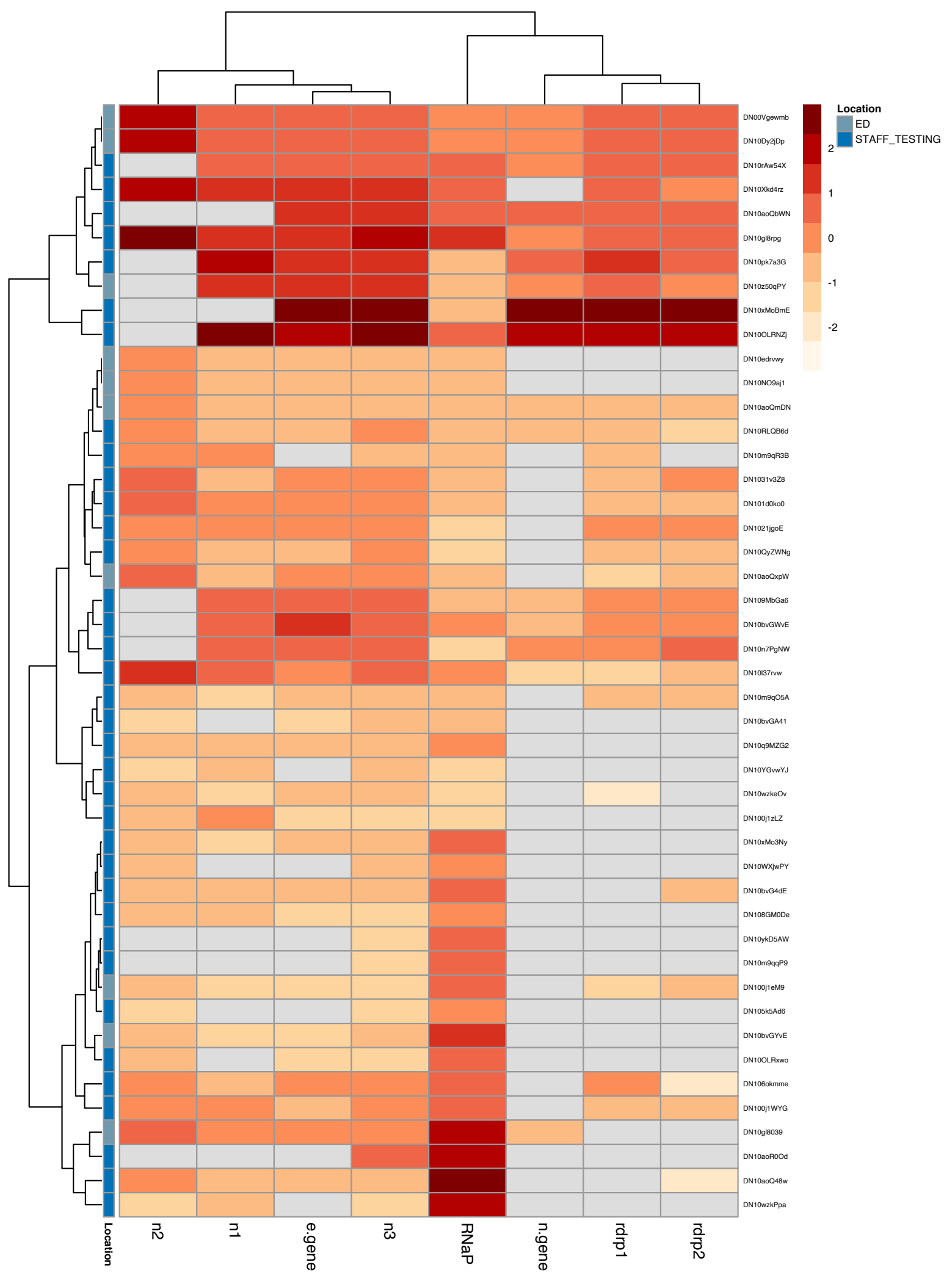

Figure 3 - Heat map illustrating SARS-CoV-2 gene targets amplified in the CovidNudge point of care test. Rows correspond to samples and columns correspond to target genes spotted on the amplification unit of the CovidNudge cartridge. Illustrated are samples testing positive on the point of care platform, corresponding to samples where $\geq 2$ replicates of at least one viral gene target amplified with $\geq 3$ human $R N$ aseP control replicates amplifying. Displayed are mean c values for each gene target amplified, corresponding to the inflection point of the sigmoid reaction curve, where the PCR reaction stops its exponential growth phase and begins its exponential decay phase. ${ }^{20}$ The c values are scaled using min-max normalisation, with a bigher score corresponding to lower cycle number. Targets not amplified are displayed in grey. Clustering by Euclidean distance. 
medRxiv preprint doi: https://doi.org/10.1101/2020.08.13.20174193; this version posted August 15, 2020. The copyright holder for this preprint (which was not certified by peer review) is the author/funder, who has granted medRxiv a license to display the preprint in It is made available under a CC-BY-NC-ND 4.0 International license .

12. SUPPLEMENTARY INFORMATION

A

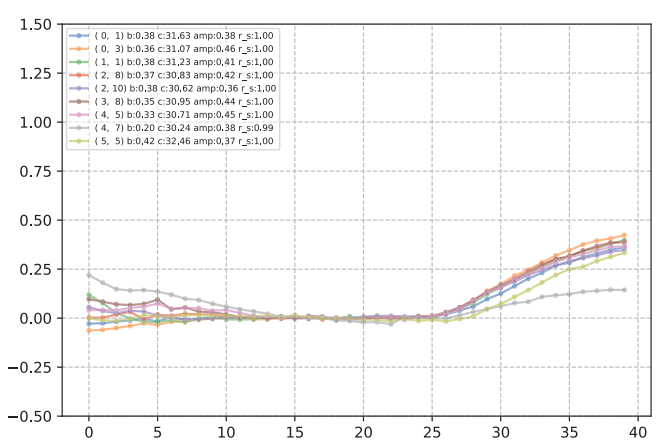

C

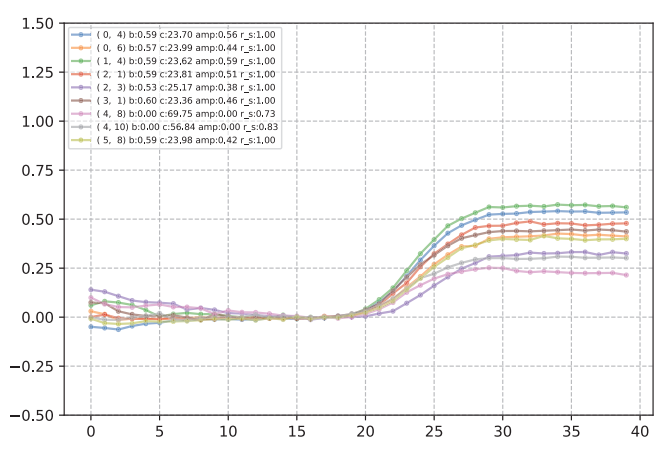

E

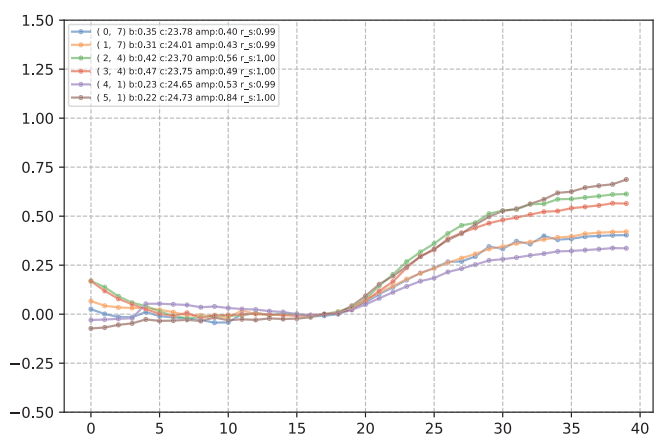

G

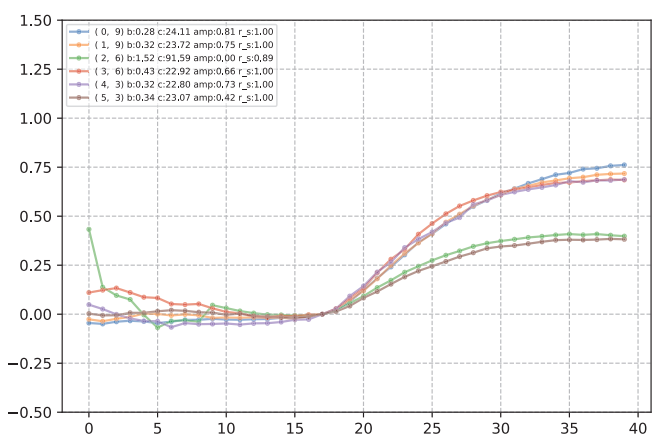

B

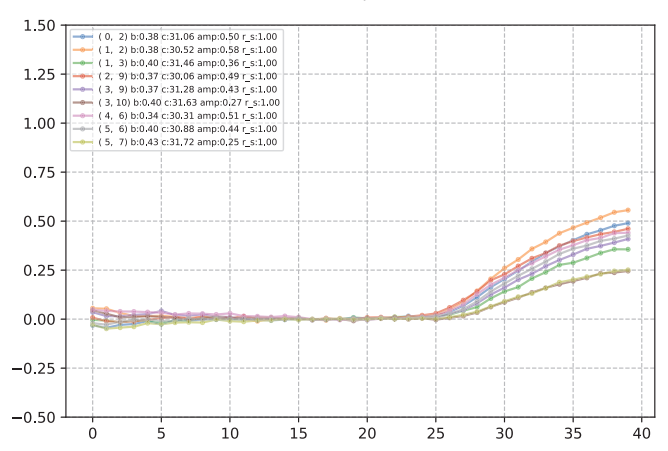

D
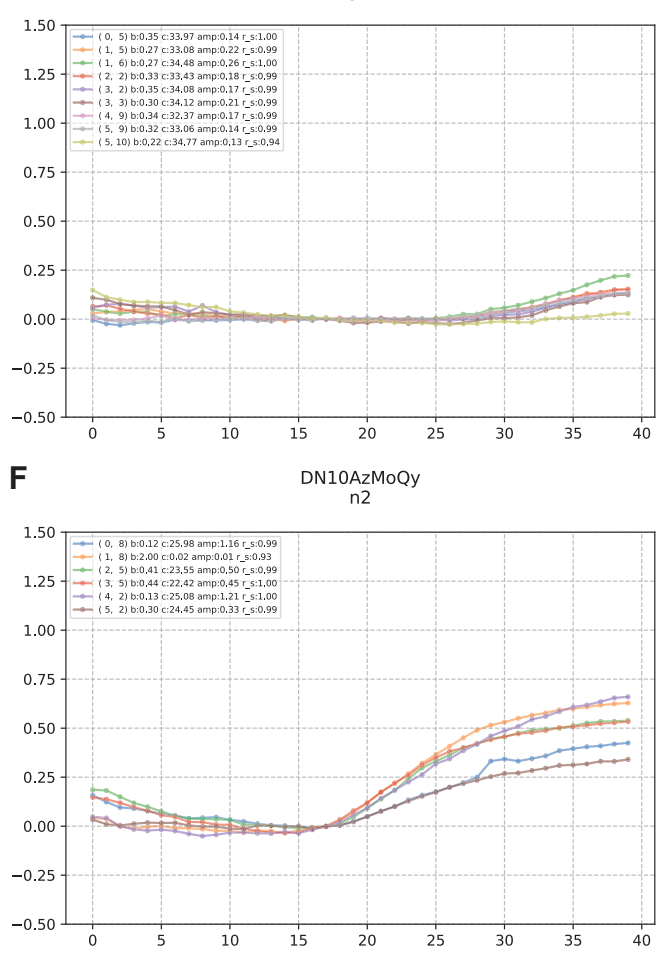

H $\underset{\text { RNAP }}{\text { DN10AMoQy }}$

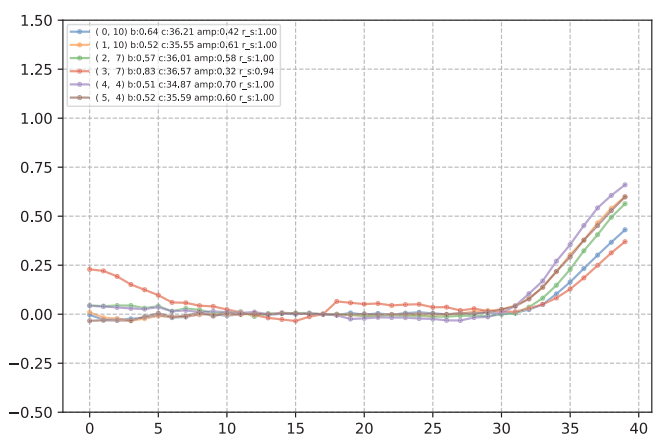

Supplementary Figure 1 - Representative reaction curve plots for strongly positive SARS-CoV-2 PCR. Displayed are reaction curves for target genes (A) rdrp1; (B) rdrp2; (C) e-gene; (D) n-gene; (E) $n 1 ;(F) n 2$ and $(G) n 3$. in the assay with accompanying technical replicates. $X$-axis corresponds to cycle number and $Y$-axis corresponds to fluorescence index. For a well to be classified as having amplified, the data should reflect the exponential growth and decay of a PCR reaction and be "sigmoid-like" according to a pre-defined algorithm (see Supplementary Methods). 
medRxiv preprint doi: https://doi.org/10.1101/2020.08.13.20174193; this version posted August 15, 2020. The copyright holder for this preprint (which was not certified by peer review) is the author/funder, who has granted medRxiv a license to display the preprint in It is made available under a CC-BY-NC-ND 4.0 International license.

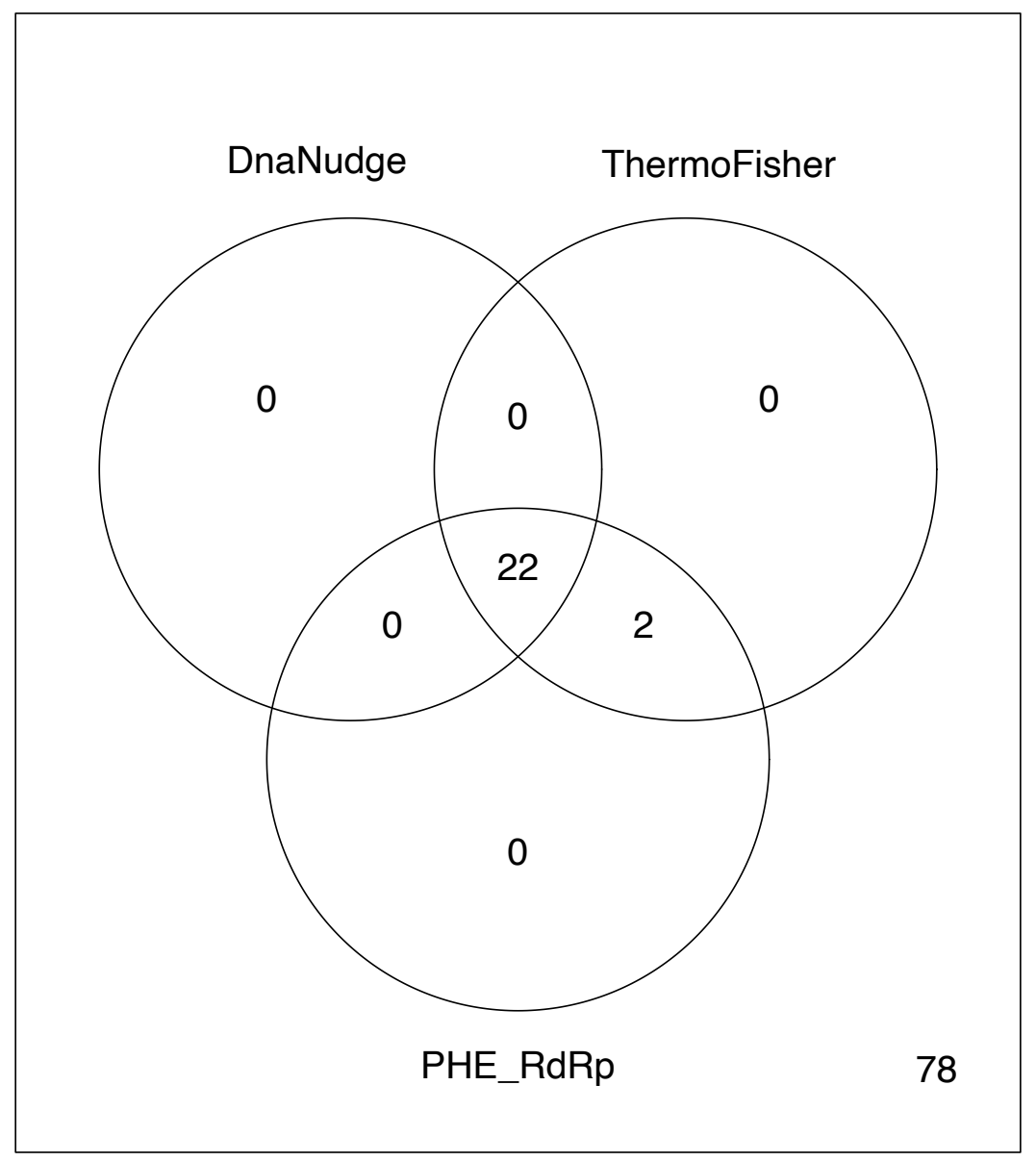

Supplementary Figure 2-Venn diagram illustrating cross assay assessment. One bundred and two samples (all collected at the John Radcliffe Hospital, Oxford) were run concurrently on three RT-PCR assays. Numbers displayed in overlapping circles represent the number of positive tests per labelled assay 
medRxiv preprint doi: https://doi.org/10.1101/2020.08.13.20174193; this version posted August 15, 2020. The copyright holder for this preprint (which was not certified by peer review) is the author/funder, who has granted medRxiv a license to display the preprint in It is made available under a CC-BY-NC-ND 4.0 International license.

308 
medRxiv preprint doi: https://doi.org/10.1101/2020.08.13.20174193; this version posted August 15, 2020. The copyright holder for this preprint (which was not certified by peer review) is the author/funder, who has granted medRxiv a license to display the preprint in It is made available under a CC-BY-NC-ND 4.0 International license .

\section{SUPPLEMENTARY METHODS}

\section{Laboratory Testing}

310

311 The Public Health England assay is a real-time RT-PCR assay targets a 100bp fragment from a conserved

312 region of the SARS-CoV-2 RNA-dependent-RNA polymerase (RdRp). ${ }^{29}$ The AusDiagnostics (New South

313 Wales, Australia) assay is a multiplex-tandem polymerase chain reaction (MT-PCR) targeting the conserved region of Orflab and Orf8 from the SARS-CoV-2 genome. RNA extraction was undertaken using the

315 Qiagen EZ1 or the AusDiagnostics MT-Prep kit. Samples process at the Imperial Molecular Diagnostics 316 Unit SARS-CoV-2 were analyzed using real-time quantitative PCR monitored by a FAM-conjugated probe 317 in a BioRad (California, United Statea) CFX Real Time PCR system, using E-gene primers and probe reported as reported by Corman et al. 7 RNA extracted from patient samples was carried out on the Felix

319 liquid handling robot and amplified using real-time quantitative PCR monitored by a FAM-conjugated 320 probe in a BioRad CFX Real Time PCR system. The Roche (Basel, Switzerland) assay is a is a dual-target 321 real-time RT-PCR assay targeting conserved regions Orf1ab and E-genes, processed on the Roche 6800 322 platform. The Abbott (Illinois, United States) real-time SARS-CoV-2 assay is a dual-target real-time RT323 PCR assay targeting conserved regions of the RdRp and N-genes, run on an Abbott M2000 machine. ${ }^{19}$ The

324 ThermoFisher (Massachusetts, United States) assay is a multiplex real-time RT-PCR with primers and 325 probes targeting orf1 ab, the spike ( $S$ gene and the nucleocapsid $(N)$ gene, as well as incorporating an RNaseP control. Extraction was undertaken on a FeliX liquid handling robot with amplification on an Analytik Jena

327 qTower.

\section{CovidNudge protocol}

330 To start a test, the user scans the cartridge barcode using the capsule. After placing the cartridge into the

331 NudgeBox and the Capsule on its top lid on the NudgeBox, the user can start the test by pressing the

332 Capsule button. The Capsule informs the NudgeBox of the DnaCartridge barcode, and the NudgeBox 
medRxiv preprint doi: https://doi.org/10.1101/2020.08.13.20174193; this version posted August 15, 2020. The copyright holder for this

preprint (which was not certified by peer review) is the author/funder, who has granted medRxiv a license to display the preprint in

It is made available under a CC-BY-NC-ND 4.0 International license .

333 communicates that with the DnaNudge cloud to register a new test or abort in case it is an invalid barcode

334 (e.g. previously used).

335

336 The test starts with moving the lysis buffer to the swab chamber by rotating and depressurising/pressurising

337 the mixing chamber between lysis and swab chambers. The lysis kills and deactivates the viral sample and

338 releases the sample RNA. Silica frit filters are mounted on to the port in the mixing chamber which can

339 capture RNA molecules. By moving back the lysis buffer from the swab chamber to the mixing chamber,

340 the extracted RNA strands bind to the silica frit. In the next step, wash buffer is passed through the mixing

341 chamber and the frit to remove any debris. In the third step, the elution buffer releases the RNA strands

342 from the frit. By turning the mixing chamber toward the master mix chamber, the elution buffer containing

343 the sample RNA is used to reconstitute the lyophilised RT master mix. This action is repeated to create a

344 homogenous mix. In the last step of sample preparation, mixing chamber turns toward the AU filling port

345 of the SPU to fill the AU.

346

347 Once the AU is filled, the NudgeBox clamps the AU between lower and upper thermal subsystems. This

348 helps with filling the reaction wells and ensures that there is no carry over between any two neighbouring

349 wells. The RT-PCR starts with a reverse transcriptase step at $45^{\circ} \mathrm{C}$ for 5 minutes, a 2-minute RT inactivation

350 and Taq activation step at $95^{\circ} \mathrm{C}$, followed by 40 cycles of PCR $\left(3\right.$-second denaturation steps at $95^{\circ} \mathrm{C}$ and

35130 -second annealing/extension steps at $60^{\circ} \mathrm{C}$ ). At the end of every annealing/extension step, the imaging

352 system measures the light intensity of every reaction well.

353

354 Exposed surfaces of the instrument are cleaned regularly between operators with $10 \%$ bleach, followed by

355 an IPA wipe to remove any residual bleach. Following the test, the cartridge is disposed

356 of following standard laboratory disposal procedures. 
medRxiv preprint doi: https://doi.org/10.1101/2020.08.13.20174193; this version posted August 15, 2020. The copyright holder for this preprint (which was not certified by peer review) is the author/funder, who has granted medRxiv a license to display the preprint in It is made available under a CC-BY-NC-ND 4.0 International license.

Primers and Probes

\begin{tabular}{|c|c|}
\hline Name & Sequence \\
\hline $\begin{array}{l}\text { 2019-nCoV_N1 } \\
\text { Forward primer }\end{array}$ & GAC CCC AAA ATC AGC GAA AT \\
\hline $\begin{array}{l}\text { 2019-nCoV_N1 } \\
\text { Reverse primer }\end{array}$ & TCT GGT TAC TGC CAG TTG AAT CTG \\
\hline $\begin{array}{l}\text { 2019-nCoV_N1 } \\
\text { Probe }\end{array}$ & /56-FAM/ACC CCG CAT TAC GTT TGG TGG ACC/36-TAMSp/ \\
\hline $\begin{array}{l}\text { 2019-nCoV_N2 } \\
\text { Forward primer }\end{array}$ & TTA CAA ACA TTG GCC GCA AA \\
\hline $\begin{array}{l}\text { 2019-nCoV_N2 } \\
\text { Reverse primer }\end{array}$ & GCG CGA CAT TCC GAA GAA \\
\hline $\begin{array}{l}\text { 2019-nCoV_N2 } \\
\text { Probe }\end{array}$ & /56-FAM/ACA ATT TGC CCC CAG CGC TTC AG/36-TAMSp/ \\
\hline $\begin{array}{l}\text { 2019-nCoV_N3 } \\
\text { Forward primer }\end{array}$ & GGG AGC CTT GAA TAC ACC AAA A \\
\hline $\begin{array}{l}\text { 2019-nCoV_N3 } \\
\text { Reverse primer }\end{array}$ & TGT AGC ACG ATT GCA GCA TTG \\
\hline $\begin{array}{l}\text { 2019-nCoV_N3 } \\
\text { Probe }\end{array}$ & /56-FAM/AYC ACA TTG GCA CCC GCA ATC CTG/36-TAMSp/ \\
\hline $\begin{array}{l}\text { RdRP_SARSr } \\
\text { Forward Primer }\end{array}$ & GTGARATGGTCATGTGTGGCGG \\
\hline $\begin{array}{l}\text { RdRP_SARSr } \\
\text { Reverse Primer }\end{array}$ & CARATGTTAAASACACTATTAGCATA \\
\hline $\begin{array}{l}\text { RdRP_SARSr Probe } \\
2\end{array}$ & /56-FAM/CAGGTGGAACCTCATCAGGAGATGC/36-TAMSp/ \\
\hline $\begin{array}{l}\text { RdRP_SARSr Probe } \\
1\end{array}$ & /56-FAM/CCAGGTGGWACRTCATCMGGTGATGC/36-TAMSp/ \\
\hline $\begin{array}{l}\text { E_Sarbeco } \\
\text { Forward primer }\end{array}$ & ACAGGTACGTTAATAGTTAATAGCGT \\
\hline $\begin{array}{l}\text { E_Sarbeco } \\
\text { Reverse primer }\end{array}$ & ATATTGCAGCAGTACGCACACA \\
\hline $\begin{array}{l}\text { E_Sarbeco } \\
\text { Probe }\end{array}$ & /56-FAM/ACACTAGCCATCCTTACTGCGCTTCG/36-TAMSp/ \\
\hline $\begin{array}{l}\text { N_Sarbeco } \\
\text { Forward primer }\end{array}$ & CACATTGGCACCCGCAATC \\
\hline $\begin{array}{l}\text { N_Sarbeco } \\
\text { Reverse primer }\end{array}$ & GAGGAACGAGAAGAGGCTTG \\
\hline $\begin{array}{l}\text { N_Sarbeco } \\
\text { Probe }\end{array}$ & /56-FAM/ACTTCCTCAAGGAACAACATTGCCA/36-TAMSp/ \\
\hline $\begin{array}{l}\text { RNase P Forward } \\
\text { Primer }\end{array}$ & AGA TTTT GGA CCT GCG AGC G \\
\hline $\begin{array}{l}\text { RNase P Reverse } \\
\text { Primer }\end{array}$ & GAG CGG CTG TCT CCA CAA GT \\
\hline RNase P Probe & /56-FAM/TTC TGA CCT GAA GGC TCT GCG CG/36-TAMSp/ \\
\hline
\end{tabular}


medRxiv preprint doi: https://doi.org/10.1101/2020.08.13.20174193; this version posted August 15, 2020. The copyright holder for this preprint (which was not certified by peer review) is the author/funder, who has granted medRxiv a license to display the preprint in It is made available under a CC-BY-NC-ND 4.0 International license

359 Exclusivity of the assays with respect to the Coronaviridae family was evaluated in silico by mapping the

360 primer and probe sequences to homologous sequences downloaded from the NCBI database. The WHO

361 N-gene, WHO E-gene and WHO RdRp-1 assays are predicted to detect human SARS-coronavirus and bat

362 SARS-like coronaviruses in the subgenus Sarbecovirus. CDC N3 assay may also detect Sarbecovirus other

363 than SARS-CoV-2. No cross-reactivity with human coronaviruses OC43, HKU1, NL63, 229E or MERS-

364 coronavirus was detected for any assays. NCBI primer-BLAST tool was used to assess potential cross-

365 reactivity with other respiratory pathogens and high-priority organisms. No unintended cross-reactivity was

366 detected for any organisms listed below:

367

\begin{tabular}{|l|l|}
\hline Organism & \\
\hline Adenovirus A/B/C/D/E & Haemophilus influenzae \\
\hline Enterovirus A/B/C & Legionella \\
\hline Human metapneumovirus & Leptospira \\
\hline Influenza A/B/C & Moraxella catarrbalis \\
\hline Parainfluenza virus 1-4 & Mycobacterium tuberculosis \\
\hline Parechovirus & Mycoplasma pneumoniae \\
\hline Respiratory syncytial virus & Neisseria elongate \\
\hline Rhinovirus A/B & Neisseria meningitidis \\
\hline Bacillus anthracis & Pneumocystis jirovecii \\
\hline Bordetella pertussis & Pseudomonas aeruginosa \\
\hline Candida albicans & Staphylococcus aureus \\
\hline Chlamydia pneumoniae & Streptococcus pneumoniae \\
\hline Chlamydia psittaci & \\
\hline
\end{tabular}


medRxiv preprint doi: https://doi.org/10.1101/2020.08.13.20174193; this version posted August 15, 2020. The copyright holder for this preprint (which was not certified by peer review) is the author/funder, who has granted medRxiv a license to display the preprint in It is made available under a CC-BY-NC-ND 4.0 International license .

\section{PCR analysis}

371 Analysis from individual wells is subdivided into model fitting, post-processing and classification stages.

372 The data is modelled by the following formula:

$$
f(x)=\frac{a}{1+e^{-b(x-c)}}+d+e x
$$

374 Where $\mathrm{x}$ is the PCR cycle. The first term, consisting of parameters $a, b$, and $c$ ("the sigmoid term") describe

375 the exponential growth and decay in fluorescence intensity during a test. Parameters $d$ and $e$ account for system nonidealities, inter-test and inter-instrument variability. Raw data is fitted to the model with leastsquares curve fitting techniques which provides estimates for parameters $a, b$ and $c$. To ensure well to well and test to test consistency, data from each well undergoes drift correction and normalisation. Using the model parameters calculated previously the data is re-simulated with the $\boldsymbol{e}$ parameter set to zero and multiplying the remaining terms by a normalisation factor.

$$
\operatorname{Norm}[f(x)]=\gamma \cdot\left(\frac{a}{1+e^{-b(x-c)}}+d+0 \cdot x\right)
$$

Where $\gamma$ is the normalisation factor.

384 For a well to be classified as having amplified, the data should reflect the exponential growth and decay of

385 a PCR reaction, simply, it should be "sigmoid-like". This implies that the model parameters should fall 386 within appropriate ranges. Specifically, inspection of the $\boldsymbol{b}$ and $\boldsymbol{c}$ parameters and the synthesis of two 387 additional parameters (normalised sigmoid amplitude and $\mathrm{r}^{2}$ ) allow the algorithm to classify data as "sigmoid-like" or otherwise.

$$
f(x)= \begin{cases}\text { sigmoid, } & \left\{\begin{array}{c}
b_{1}<b<b_{2} \\
c_{1}<c<c_{2} \\
a m p>a m p_{t h} \\
r^{2}>r_{t h}^{2}
\end{array}\right. \\
\text { sigmoid, } & \text { otherwise }\end{cases}
$$

390 Where $b_{1}, b_{2}, c_{1}, c_{2}$ are upper and lower bounds for $\boldsymbol{b}$ and $\boldsymbol{c}$ respectively while $a m p_{t h}$ and $r_{t h}^{2}$ are 391 thresholds over which the normalised amplitude and goodness of fit must exceed.

393 To identify the DC line and avoid the initial cycles noise, a median value of a range of midway cycles is 394 used to normalise and adjust the base line. This adjustment is to help with applying standardised rules on 
medRxiv preprint doi: https://doi.org/10.1101/2020.08.13.20174193; this version posted August 15, 2020. The copyright holder for this preprint (which was not certified by peer review) is the author/funder, who has granted medRxiv a license to display the preprint in It is made available under a CC-BY-NC-ND 4.0 International license .

395 calling a signal a positive or negative. When the sigmoid fit is applied and passes an r-squared criteria to

396 indicate if the signal could be properly modelled with sigmoid or not, the parameters helping with that fit

397 are compared against normal signal threshold values.

398

399 Initial analysis of samples collected in the emergency department at St Mary's hospital between the 2nd to

400 19th April were performed by manual inspection of amplification curves by laboratory staff blinded to the

401 results of centralized laboratory testing, assessing for the inflection point of the sigmoid reaction curve.

402 Subsequent analysis was performed algorithmically. By running the optimized algorithm on the manual data

403 before the 19th April on samples run against the AusDiagnostic platform, estimates sensitivity is reduced.

404 However, this would be expected since limits of detection on a nested PCR are a lot higher than a standard

405 RT-PCR.

406

407 Limits of detection

408 In order to measure the limits of detection (LOD) of assay of the CovidNudge platform, control RNA

409 (Twist Synthetic SARS-CoV-2 RNA Controls, Twist Biosciences, USA) was diluted to varying 410 concentrations and spiked in the RT-PCR lyophilised master mix chamber of the cartridges. Promega

411 human DNA $(\sim 0.6 \mathrm{ng} / \mathrm{ul})$ was also spiked and used as a carrier RNA to prevent any low label RNA binding

412 to plastic. Analysis was also performed using viral particles a known concentration $\left(1 \times 10^{\wedge} 6\right.$ copies per $\left.\mathrm{mL}\right)$

413 in a proprietary matrix were purchased from ZeptoMetrix, Product Desription: NATtrol SARS-Related

414 Coronavirus 2(SARS-CoV-2), Stock, Cat No: NATSARS(COV2)-ST). Samples were processed as outlined

415 in the CovidNudge protocol and PCR analysis sections above. 


\begin{tabular}{|c|c|c|c|c|c|c|c|c|c|}
\hline \multirow{2}{*}{$\begin{array}{l}\text { Total viral RNA } \\
\text { input (copies) }\end{array}$} & \multirow{2}{*}{$\begin{array}{c}\text { Conc. In } \\
\text { reaction (RNA } \\
\text { copies/ul) }\end{array}$} & & \multicolumn{7}{|c|}{ Target Gene } \\
\hline & & & $\begin{array}{c}\text { RdRP1 } \\
(\text { Replicates }=9)\end{array}$ & $\begin{array}{c}\text { RdRP2 } \\
(\text { Replicates }=9)\end{array}$ & $\begin{array}{c}\text { E_Sarbeco } \\
(\text { Replicates }=9)\end{array}$ & $\begin{array}{c}\text { N_Sarbeco } \\
(\text { Replicates }=9)\end{array}$ & $\begin{array}{c}\mathrm{N1} \\
(\text { Replicates }=6)\end{array}$ & $\begin{array}{c}\text { N2 } \\
(\text { Replicates }=6)\end{array}$ & $\begin{array}{c}\text { N3 } \\
(\text { Replicates }=6)\end{array}$ \\
\hline \multirow{3}{*}{$\begin{array}{l}\text { 50,000 SARS- } \\
\text { CoV-2 }\end{array}$} & \multirow{3}{*}{125} & $\begin{array}{l}\text { Number of } \\
\text { Replicates } \\
\text { Amplified }\end{array}$ & $8 / 9$ & $6 / 9$ & $9 / 9$ & $2 / 9$ & $6 / 6$ & $6 / 6$ & $6 / 6$ \\
\hline & & $\begin{array}{c}\text { Mean Cycle } \\
\text { Threshold }\end{array}$ & 34 & 34 & 30 & 36 & 31 & 31 & 31 \\
\hline & & $\begin{array}{c}\text { End Point } \\
\text { Fluorescence }\end{array}$ & 0.35 & 0.35 & 0.8 & 0.2 & 0.7 & 0.6 & 0.7 \\
\hline \multirow{3}{*}{$\begin{array}{c}50,000 \text { SARS- } \\
\text { CoV-2 }\end{array}$} & \multirow{3}{*}{125} & $\begin{array}{l}\text { Number of } \\
\text { Replicates } \\
\text { Amplified } \\
\end{array}$ & $5 / 9$ & $6 / 9$ & $9 / 9$ & $3 / 9$ & $6 / 6$ & $6 / 6$ & $6 / 6$ \\
\hline & & $\begin{array}{c}\text { Mean Cycle } \\
\text { Threshold } \\
\end{array}$ & 35 & 33 & 31 & 36 & 32 & 30 & 30 \\
\hline & & $\begin{array}{c}\text { End Point } \\
\text { Fluorescence }\end{array}$ & 0.4 & 0.65 & 0.9 & 0.25 & 0.85 & 1.1 & 1 \\
\hline \multirow{3}{*}{$\begin{array}{c}\text { 50,000 SARS- } \\
\text { CoV-2 }\end{array}$} & \multirow{3}{*}{125} & $\begin{array}{l}\text { Number of } \\
\text { Replicates } \\
\text { Amplified } \\
\end{array}$ & $3 / 9$ & $4 / 9$ & $7 / 9$ & $2 / 9$ & $\begin{array}{l}6 / 6 \\
=\end{array}$ & $6 / 6$ & $6 / 6$ \\
\hline & & $\begin{array}{l}\text { Mean Cycle } \\
\text { Threshold }\end{array}$ & 36 & 35 & 33 & 37 & 31 & 32 & 32 \\
\hline & & $\begin{array}{c}\text { End Point } \\
\text { Fluorescence }\end{array}$ & 0.25 & 0.35 & 0.3 & 0.15 & 0.65 & 0.4 & 0.55 \\
\hline \multirow{3}{*}{$\begin{array}{c}\text { 40,000 SARS- } \\
\text { CoV-2 }\end{array}$} & \multirow{3}{*}{100} & $\begin{array}{l}\text { Number of } \\
\text { Replicates } \\
\text { Amplified } \\
\end{array}$ & $4 / 9$ & $6 / 9$ & $9 / 9$ & $\begin{array}{c}3 / 9 \\
=\end{array}$ & $6 / 6$ & $6 / 6$ & $6 / 6$ \\
\hline & & $\begin{array}{c}\text { Mean Cycle } \\
\text { Threshold }\end{array}$ & 35 & 24 & 32 & 37 & 31 & 32 & 31 \\
\hline & & $\begin{array}{l}\text { End Point } \\
\text { Fluorescence }\end{array}$ & 0.7 & 1 & 1 & 0.35 & 1 & 0.7 & 0.9 \\
\hline \multirow{3}{*}{$\begin{array}{c}\text { 40,000 SARS- } \\
\text { CoV-2 }\end{array}$} & \multirow{3}{*}{100} & $\begin{array}{l}\text { Number of } \\
\text { Replicates } \\
\text { Amplified } \\
\end{array}$ & $3 / 9$ & $5 / 9$ & $9 / 9$ & $2 / 9$ & $5 / 6$ & $6 / 6$ & $6 / 6$ \\
\hline & & $\begin{array}{l}\text { Mean Cycle } \\
\text { Threshold }\end{array}$ & 37 & 35 & 31 & 36 & 31 & 31 & 31 \\
\hline & & $\begin{array}{c}\text { End Point } \\
\text { Fluorescence } \\
\end{array}$ & 0.45 & 10.6 & 0.75 & 0.35 & 0.95 & 2 & 1.1 \\
\hline $\begin{array}{c}\text { 25,000 SARS- } \\
\text { CoV-2 }\end{array}$ & 62.5 & $\begin{array}{l}\text { Number of } \\
\text { Replicates } \\
\text { Amplified } \\
\end{array}$ & $1 / 6$ & $1 / 6$ & $3 / 6$ & $0 / 0$ & $2 / 6$ & $2 / 6$ & $5 / 6$ \\
\hline
\end{tabular}




\begin{tabular}{|c|c|c|c|c|c|c|c|c|c|}
\hline & & $\begin{array}{c}\text { Mean Cycle } \\
\text { Threshold } \\
\end{array}$ & 41 & 38 & 35 & - & 35 & 35 & 35 \\
\hline & & $\begin{array}{c}\text { End Point } \\
\text { Fluorescence }\end{array}$ & - & - & - & - & - & - & - \\
\hline \multirow{3}{*}{$\begin{array}{c}20,000 \text { SARS- } \\
\text { CoV-2 }\end{array}$} & \multirow{3}{*}{50} & $\begin{array}{l}\text { Number of } \\
\text { Replicates } \\
\text { Amplified }\end{array}$ & $1 / 9$ & $1 / 9$ & $4 / 9$ & $2 / 9$ & $1 / 6$ & $3 / 6$ & $3 / 6$ \\
\hline & & $\begin{array}{l}\text { Mean Cycle } \\
\text { Threshold }\end{array}$ & 38 & 40 & 34 & 38 & 33 & 32 & 34 \\
\hline & & $\begin{array}{l}\text { End Point } \\
\text { Fluorescence }\end{array}$ & - & - & - & - & - & - & - \\
\hline \multirow[t]{3}{*}{$\begin{array}{c}\text { 10,000 SARS- } \\
\text { CoV-2 }\end{array}$} & \multirow[t]{3}{*}{25} & $\begin{array}{l}\text { Number of } \\
\text { Replicates } \\
\text { Amplified }\end{array}$ & No amplification & No amplification & $\begin{array}{c}1 / 9 \\
\text { Ct } 35\end{array}$ & No amplification & No amplification & $3 / 6$ & $2 / 6$ \\
\hline & & $\begin{array}{l}\text { Mean Cycle } \\
\text { Threshold }\end{array}$ & - & - & 35 & - & - & 32 & 34 \\
\hline & & $\begin{array}{c}\text { End Point } \\
\text { Fluorescence }\end{array}$ & - & - & - & - & - & - & - \\
\hline \multirow{3}{*}{$\begin{array}{c}1000 \text { SARS-CoV- } \\
2\end{array}$} & \multirow{3}{*}{10} & $\begin{array}{l}\text { Number of } \\
\text { Replicates } \\
\text { Amplified }\end{array}$ & No amplification & No amplification & $3 / 9$ & No amplification & $1 / 6$ & $4 / 6$ & $6 / 6$ \\
\hline & & $\begin{array}{c}\text { Mean Cycle } \\
\text { Threshold } \\
\end{array}$ & - & - & 35 & - & 33 & 34 & 35 \\
\hline & & $\begin{array}{c}\text { End Point } \\
\text { Fluorescence }\end{array}$ & - & - & - & - & - & - & - \\
\hline \multirow{3}{*}{$\begin{array}{c}1000 \text { SARS-CoV- } \\
2\end{array}$} & \multirow{3}{*}{5} & $\begin{array}{l}\text { Number of } \\
\text { Replicates } \\
\text { Amplified } \\
\end{array}$ & No amplification & $1 / 9$ & No amplification & No amplification & No amplification & No amplification & $4 / 6$ \\
\hline & & $\begin{array}{l}\text { Mean Cycle } \\
\text { Threshold } \\
\end{array}$ & - & 35 & - & - & - & - & 34 \\
\hline & & $\begin{array}{c}\text { End Point } \\
\text { Fluorescence }\end{array}$ & - & - & - & - & - & - & - \\
\hline \multirow{3}{*}{$\begin{array}{c}1000 \text { SARS-CoV- } \\
2\end{array}$} & \multirow{3}{*}{2.5} & $\begin{array}{c}\text { Number of } \\
\text { Replicates } \\
\text { Amplified }\end{array}$ & No amplification & No amplification & No amplification & No amplification & No amplification & No amplification & No amplification \\
\hline & & $\begin{array}{l}\text { Mean Cycle } \\
\text { Threshold }\end{array}$ & - & - & - & - & - & - & - \\
\hline & & $\begin{array}{l}\text { End Point } \\
\text { Fluorescence }\end{array}$ & - & - & - & - & - & - & - \\
\hline
\end{tabular}

Supplementary Table 1 - Assessment of lower limit of detection for CovidNudge platform. Control RNA (Twist Synthetic SARS-CoV-2 RNA Controls, Twist Biosciences, US A) was diluted to varying concentrations and spiked in the RT-PCR lyophilised master mix chamber of the cartridges. Displayed are mean c values for each gene target amplified, corresponding to the inflection point of the sigmoid reaction curve, where the PCR reaction stops its exponential growth phase and begins its exponential decay phase. 


\begin{tabular}{|c|c|c|c|c|c|c|c|c|}
\hline \multirow{2}{*}{$\begin{array}{l}\text { Total Viral Particle } \\
\text { Input (copies) }\end{array}$} & & \multicolumn{7}{|c|}{ Target Gene } \\
\hline & & $\begin{array}{c}\text { RdRP1 } \\
(\text { Replicates }=9)\end{array}$ & $\begin{array}{c}\text { RdRP2 } \\
(\text { Replicates }=9)\end{array}$ & $\begin{array}{c}\text { E_Sarbeco } \\
(\text { Replicates }=9)\end{array}$ & $\begin{array}{c}\text { N_Sarbeco } \\
(\text { Replicates = 9) }\end{array}$ & $\begin{array}{c}\mathrm{N1} \\
\text { (Replicates }=6)\end{array}$ & $\begin{array}{c}\mathrm{N} 2 \\
\text { (Replicates }=6)\end{array}$ & $\begin{array}{c}\mathrm{N3} \\
(\text { Replicates }=6)\end{array}$ \\
\hline \multirow{2}{*}{100,000 SARS-CoV-2 } & $\begin{array}{l}\text { Number of } \\
\text { Replicates } \\
\text { Amplified }\end{array}$ & No amplification & No amplification & $2 / 9$ & No amplification & No amplification & $3 / 6$ & $3 / 6$ \\
\hline & $\begin{array}{c}\text { Mean Cycle } \\
\text { Threshold }\end{array}$ & - & - & 35 & - & - & 36 & 35 \\
\hline \multirow[t]{2}{*}{75,000 SARS-CoV-2 } & $\begin{array}{l}\text { Number of } \\
\text { Replicates } \\
\text { Amplified }\end{array}$ & No amplification & No amplification & No amplification & No amplification & No amplification & $3 / 6$ & $3 / 6$ \\
\hline & $\begin{array}{c}\text { Mean Cycle } \\
\text { Threshold }\end{array}$ & - & - & - & - & - & 38 & 35 \\
\hline \multirow[t]{2}{*}{50,000 SARS-CoV-2 } & $\begin{array}{l}\text { Number of } \\
\text { Replicates } \\
\text { Amplified } \\
\end{array}$ & $2 / 9$ & No amplification & $1 / 9$ & No amplification & $1 / 6$ & $1 / 6$ & $6 / 6$ \\
\hline & $\begin{array}{c}\text { Mean Cycle } \\
\text { Threshold }\end{array}$ & 35 & - & 35 & - & 38 & 38 & 37 \\
\hline \multirow[t]{2}{*}{50,000 SARS-CoV-2 } & $\begin{array}{l}\text { Number of } \\
\text { Replicates } \\
\text { Amplified }\end{array}$ & No amplification & No amplification & $1 / 9$ & No amplification & No amplification & No amplification & $1 / 6$ \\
\hline & $\begin{array}{c}\text { Mean Cycle } \\
\text { Threshold }\end{array}$ & - & - & 33 & - & - & - & 35 \\
\hline \multirow[t]{2}{*}{50,000 SARS-CoV-2 } & $\begin{array}{l}\text { Number of } \\
\text { Replicates } \\
\text { Amplified }\end{array}$ & No amplification & No amplification & $1 / 9$ & No amplification & No amplification & No amplification & $1 / 6$ \\
\hline & $\begin{array}{c}\text { Mean Cycle } \\
\text { Threshold }\end{array}$ & - & - & 34 & - & - & - & 37 \\
\hline \multirow[t]{2}{*}{10,000 SARS-CoV-2 } & $\begin{array}{l}\text { Number of } \\
\text { Replicates } \\
\text { Amplified }\end{array}$ & No amplification & No amplification & No amplification & No amplification & No amplification & No amplification & $2 / 6$ \\
\hline & $\begin{array}{c}\text { Mean Cycle } \\
\text { Threshold }\end{array}$ & - & - & - & - & - & - & 36 \\
\hline \multirow[t]{2}{*}{10,000 SARS-CoV-2 } & $\begin{array}{l}\text { Number of } \\
\text { Replicates } \\
\text { Amplified }\end{array}$ & No amplification & No amplification & No amplification & No amplification & $1 / 6$ & No amplification & No amplification \\
\hline & $\begin{array}{c}\text { Mean Cycle } \\
\text { Threshold }\end{array}$ & - & - & - & - & 36 & - & - \\
\hline \multirow[t]{2}{*}{10,000 SARS-CoV-2 } & $\begin{array}{l}\text { Number of } \\
\text { Replicates } \\
\text { Amplified }\end{array}$ & No amplification & No amplification & No amplification & No amplification & $3 / 6$ & No amplification & No amplification \\
\hline & $\begin{array}{c}\text { Mean Cycle } \\
\text { Threshold }\end{array}$ & - & - & - & - & 35 & - & - \\
\hline
\end{tabular}




\begin{tabular}{|c|c|c|c|c|c|c|c|c|}
\hline \multirow{2}{*}{10,000 SARS-CoV-2 } & $\begin{array}{l}\text { Number of } \\
\text { Replicates } \\
\text { Amplified }\end{array}$ & No amplification & No amplification & No amplification & No amplification & No amplification & No amplification & $1 / 6$ \\
\hline & $\begin{array}{l}\text { Mean Cycle } \\
\text { Threshold }\end{array}$ & - & - & - & - & - & - & 36 \\
\hline \multirow[t]{2}{*}{10,000 SARS-CoV-2 } & $\begin{array}{c}\text { Number of } \\
\text { Replicates } \\
\text { Amplified }\end{array}$ & No amplification & No amplification & No amplification & No amplification & $1 / 6$ & $1 / 6$ & No amplification \\
\hline & $\begin{array}{c}\text { Mean Cycle } \\
\text { Threshold }\end{array}$ & - & - & - & - & 33 & 41 & - \\
\hline
\end{tabular}

Supplementary Table 2 - Assessment of lower limit of detection for CovidNudge platform using test SARS-CoV-2 viral particles. Control viral particles (Zeptometrix NATrol SARS-CoV-2 RNA Controls) was diluted to varying concentrations and spiked in the RT-PCR hysis chamber of the cartridges. Displayed are mean c values for each gene target amplified, corresponding to the inflection point of the sigmoid reaction curve, where the PCR reaction stops its exponential growth phase and begins its exponential decay phase. 


\begin{tabular}{|c|c|c|c|c|c|c|c|c|c|c|c|}
\hline & & \multicolumn{2}{|c|}{ Laboratory Testing } & \multicolumn{2}{|c|}{ Point of Care Testing } & \multirow[b]{2}{*}{ Prevalence } & \multirow[b]{2}{*}{$\begin{array}{c}\text { Sensitivity } \\
(95 \% \mathrm{CI})\end{array}$} & \multirow[b]{2}{*}{$\begin{array}{c}\text { Specificity } \\
(95 \% \mathrm{CI})\end{array}$} & \multirow[b]{2}{*}{$\begin{array}{c}\text { Positive } \\
\text { Predictive } \\
\text { Value } \\
(95 \% \mathrm{CI})\end{array}$} & \multirow[b]{2}{*}{$\begin{array}{c}\text { Negative } \\
\text { Predictive } \\
\text { Value } \\
(95 \% \mathrm{CI})\end{array}$} & \multirow[b]{2}{*}{$\begin{array}{c}\text { Negative } \\
\text { Likelihood } \\
\text { Ratio } \\
\mathbf{( 9 5 \% ~ C I ~}\end{array}$} \\
\hline & Tested (n) & Positive & Negative & Positive & Negative & & & & & & \\
\hline \multicolumn{12}{|l|}{ Site } \\
\hline St Mary's Hospital, London & 162 & 34 & 128 & 33 & 129 & $\begin{array}{c}0.21(0.15 \\
0.28)\end{array}$ & $\begin{array}{c}0.97(0.85 \\
1.00)\end{array}$ & $\begin{array}{c}1.00(0.97 \\
1.00)\end{array}$ & $\begin{array}{c}1.00(0.89 \\
1.00)\end{array}$ & $\begin{array}{c}0.99(0.96 \\
1.00)\end{array}$ & $\begin{array}{c}0.03(0.00 \\
0.22)\end{array}$ \\
\hline Chelsea \& Westminster Hospital, London & 91 & 3 & 88 & 3 & 88 & $\begin{array}{c}0.03(0.01 \\
0.09)\end{array}$ & $\begin{array}{c}1.00(0.29 \\
1.00)\end{array}$ & $\begin{array}{c}1.00(0.96 \\
1.00)\end{array}$ & $\begin{array}{c}1.00(0.29 \\
1.00)\end{array}$ & $\begin{array}{c}1.00(0.96 \\
1.00))\end{array}$ & $\begin{array}{c}0.00(0.00 \\
\mathrm{NaN})\end{array}$ \\
\hline John Radcliffe Hospital, Oxford & 133 & 34 & 99 & 31 & 102 & $\begin{array}{c}0.26(0.18 \\
0.34)\end{array}$ & $\begin{array}{c}0.91(0.76 \\
0.98)\end{array}$ & $\begin{array}{c}1.00(0.96 \\
1.00)\end{array}$ & $\begin{array}{c}1.00(0.89 \\
1.00)\end{array}$ & $\begin{array}{c}0.97(0.92 \\
0.99)\end{array}$ & $\begin{array}{c}0.09(0.03 \\
0.26)\end{array}$ \\
\hline \multicolumn{12}{|l|}{ Laboratory Assay } \\
\hline AusDiagnostics_High-Plex & 74 & 25 & 49 & 24 & 50 & $\begin{array}{c}0.34(0.23 \\
0.46)\end{array}$ & $\begin{array}{c}0.96(0.80 \\
1.00)\end{array}$ & $\begin{array}{c}1.00(0.93 \\
1.00)\end{array}$ & $\begin{array}{c}1.00(0.86 \\
1.00)\end{array}$ & $\begin{array}{c}0.98(0.89 \\
1.00)\end{array}$ & $\begin{array}{c}0.04(0.01, \\
0.27)\end{array}$ \\
\hline ROCHE & 81 & 5 & 76 & 5 & 76 & $\begin{array}{c}0.06(0.02 \\
0.14)\end{array}$ & $\begin{array}{c}1.00(0.48 \\
1.00)\end{array}$ & $\begin{array}{c}1.00(0.95 \\
1.00)\end{array}$ & $\begin{array}{c}1.00(0.48 \\
1.00)\end{array}$ & $\begin{array}{c}1.00(0.95 \\
1.00)\end{array}$ & $\begin{array}{c}0.00(0.00 \\
\mathrm{NaN})\end{array}$ \\
\hline$A B B O T T$ & 66 & 4 & 62 & 2 & 64 & $\begin{array}{c}0.06(0.02 \\
0.15)\end{array}$ & $\begin{array}{c}0.50(0.07 \\
0.93)\end{array}$ & $\begin{array}{c}1.00(0.94 \\
1.00)\end{array}$ & $\begin{array}{c}1.00(0.16 \\
1.00)\end{array}$ & $\begin{array}{c}0.97(0.89 \\
1.00)\end{array}$ & $\begin{array}{c}0.50(0.19 \\
1.33)\end{array}$ \\
\hline ThermoFisher & 21 & 0 & 21 & 0 & 21 & $\begin{array}{c}0.00(0.00 \\
0.16)\end{array}$ & - & $\begin{array}{c}1.00(0.84 \\
1.00)\end{array}$ & - & $\begin{array}{c}1.00(0.84, \\
1.00)\end{array}$ & - \\
\hline Public Health England - RdRp & 120 & 32 & 88 & 31 & 89 & $\begin{array}{c}0.27(0.19 \\
0.36)\end{array}$ & $\begin{array}{c}0.97(0.84 \\
1.00)\end{array}$ & $\begin{array}{c}1.00(0.96 \\
1.00)\end{array}$ & $\begin{array}{c}1.00(0.89 \\
1.00)\end{array}$ & $\begin{array}{c}0.99(0.94 \\
1.00)\end{array}$ & $\begin{array}{c}0.03(0.00 \\
0.22)\end{array}$ \\
\hline Imperial Molecular Diagnostics Unit & 24 & 5 & 19 & 5 & 19 & $\begin{array}{c}0.21(0.05 \\
0.51)\end{array}$ & $\begin{array}{c}1.00(0.48 \\
1.00)\end{array}$ & $\begin{array}{c}1.00(0.82 \\
1.00)\end{array}$ & $\begin{array}{c}1.00(0.48 \\
1.00)\end{array}$ & $\begin{array}{c}1.00(0.82 \\
1.00)\end{array}$ & $\begin{array}{c}0.00(0.00 \\
\mathrm{NaN})\end{array}$ \\
\hline
\end{tabular}

Supplementary Table 3 - Assessment of point of care testing in paired samples collected contemporaneously presented by study site and comparator laboratory assay. 


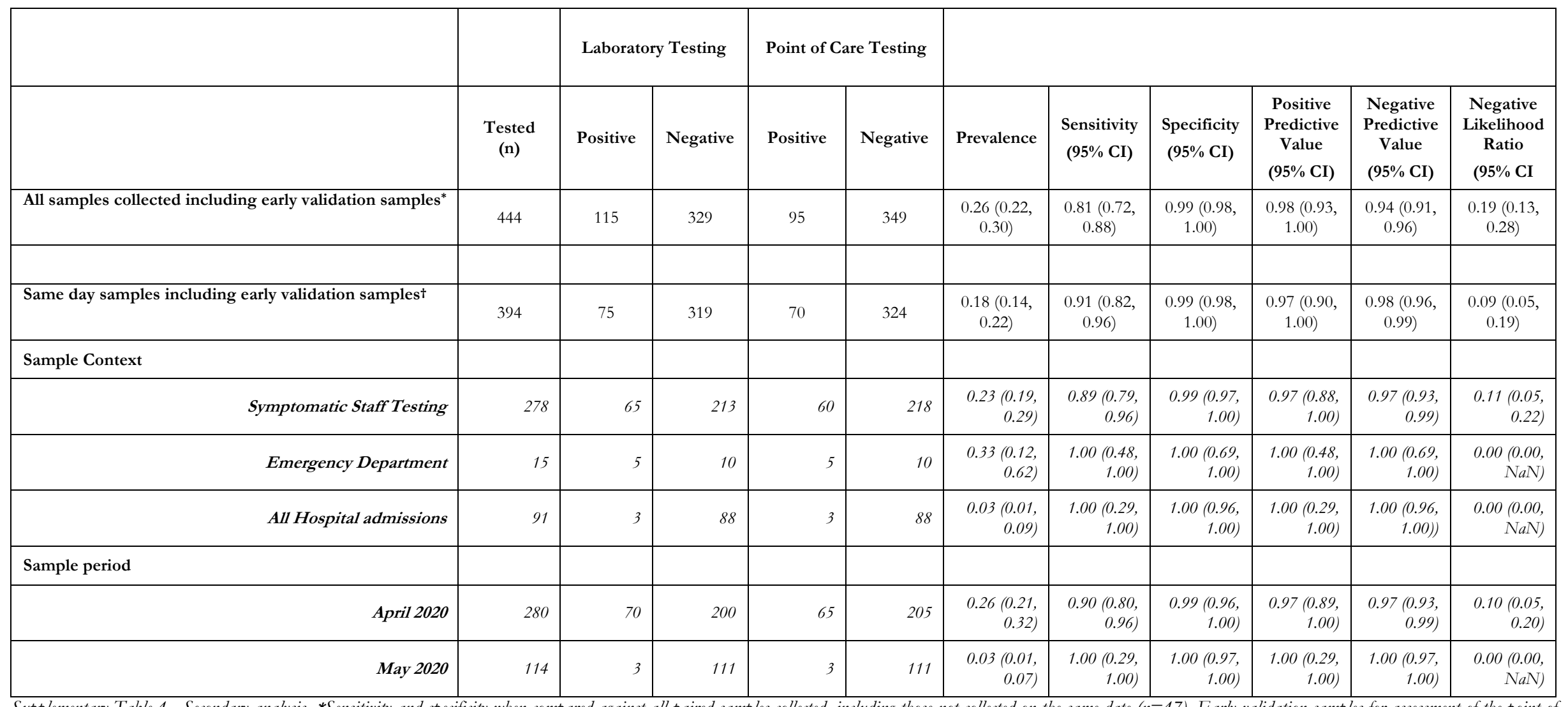

Supplementary Table 4 - Secondary analysis. *Sensitivity and specificity when compared against all paired samples collected, including those not collected on the same date ( $n=47)$. Early validation samples for assessment of the point of care test in included samples collected from patients admitted to hospital with COVID-19 confirmed on nasopharyngeal swabs tested in a central laboratory. The median interval between sample collection for laboratory processing and point of care testing was 4 days (interquartile range 1 to 7 ). $t$ All same-day samples including early validation samples collected prior to algorithm optimisation ( $n=10$ valid samples ran on Abbott platform at Oxford). 
medRxiv preprint doi: https://doi.org/10.1101/2020.08.13.20174193; this version posted August 15, 2020. The copyright holder for this preprint (which was not certified by peer review) is the author/funder, who has granted medRxiv a license to display the preprint in It is made available under a CC-BY-NC-ND 4.0 International license. 


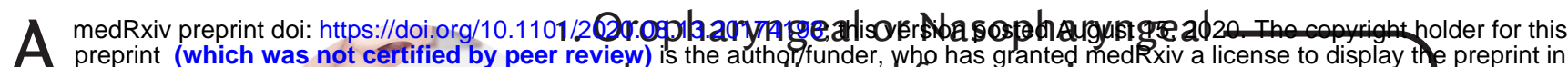

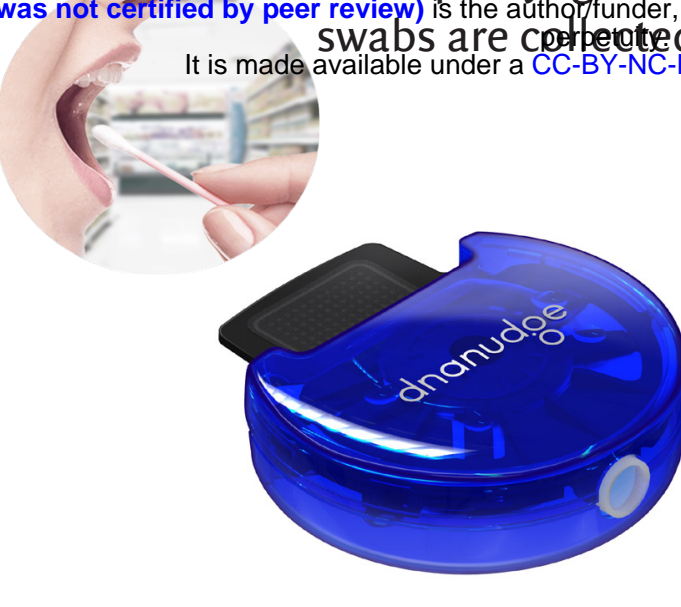

Dimensions: $25 \mathrm{~mm} \times 78 \mathrm{~mm} \times 45 \mathrm{~mm}$

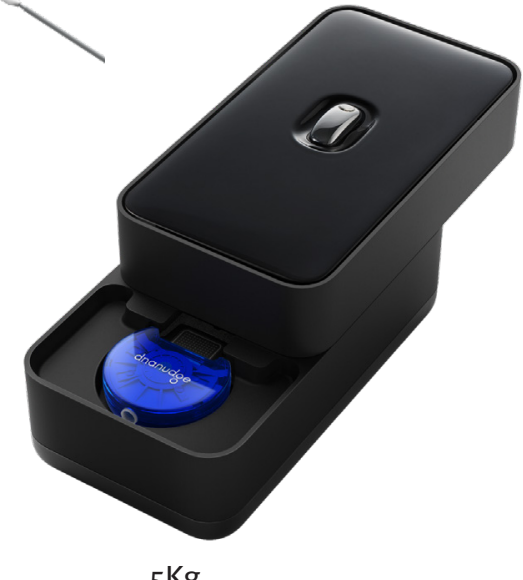

Dimensions: 280mmx155mmx135mm sample processing unit.

2. Swabs are inserted directly into the

3. The DnaCartridge barcode is scanned with the operator Capsule and placed into the NudgeBox.

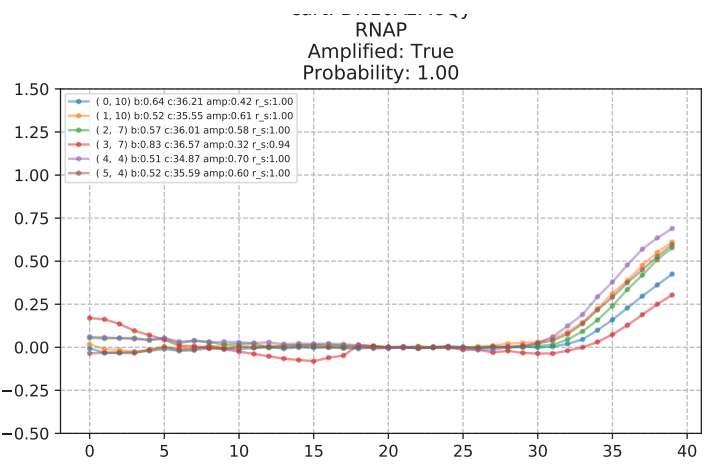

A real time PCR reaction takes place within the amplification unit.

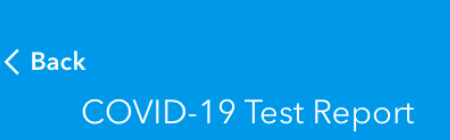

Time to result: 60 to 90 minutes.

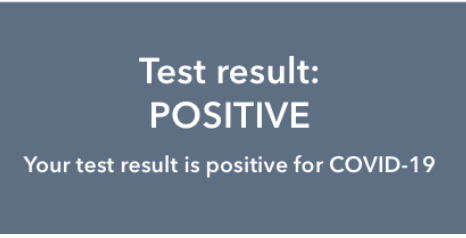

5. Each device is linked to a cloud-based database via WiFi, where test data are analysed and the results sent directly to a patient's electronic health record or smartphone app.

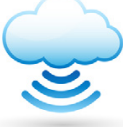

B

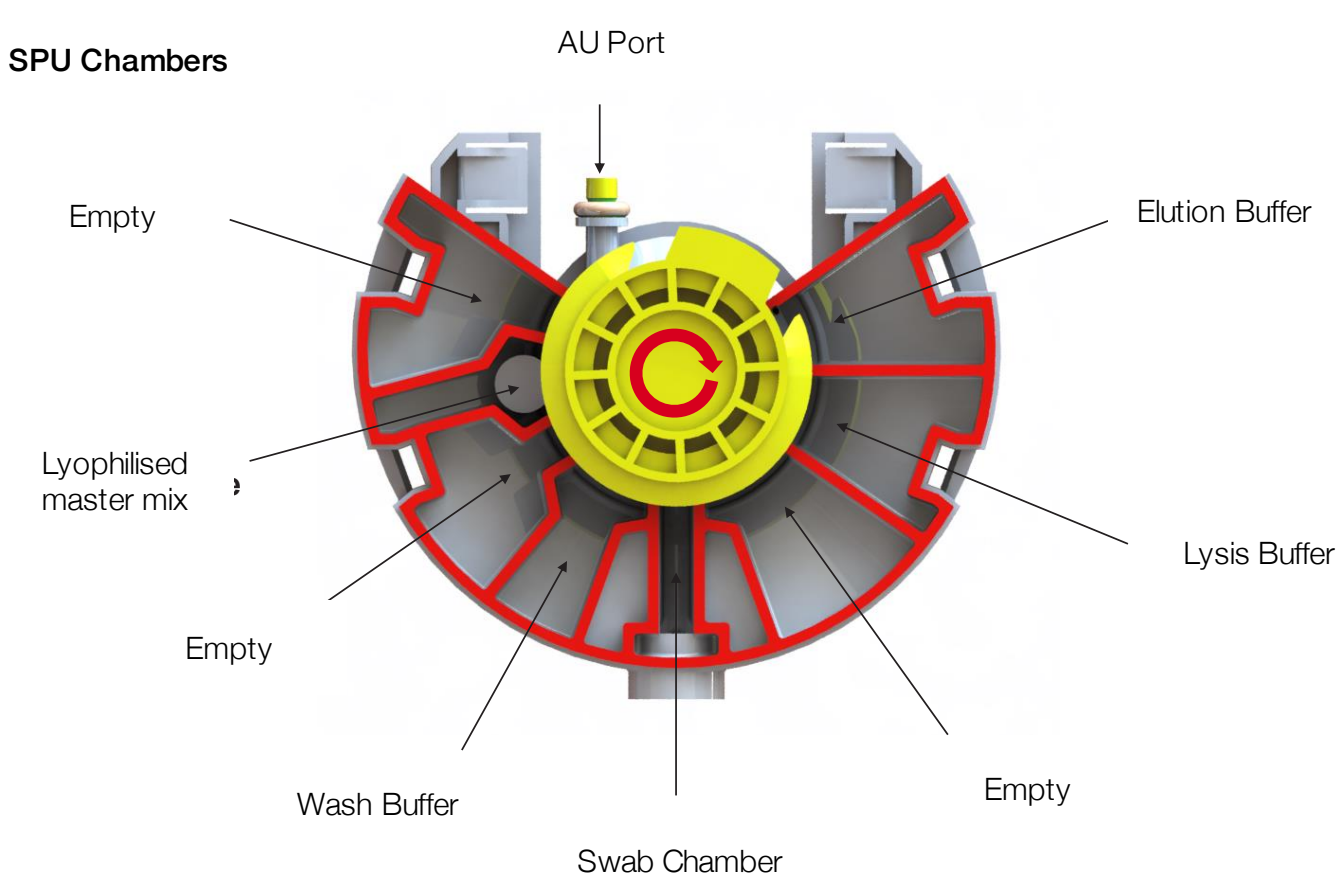

C
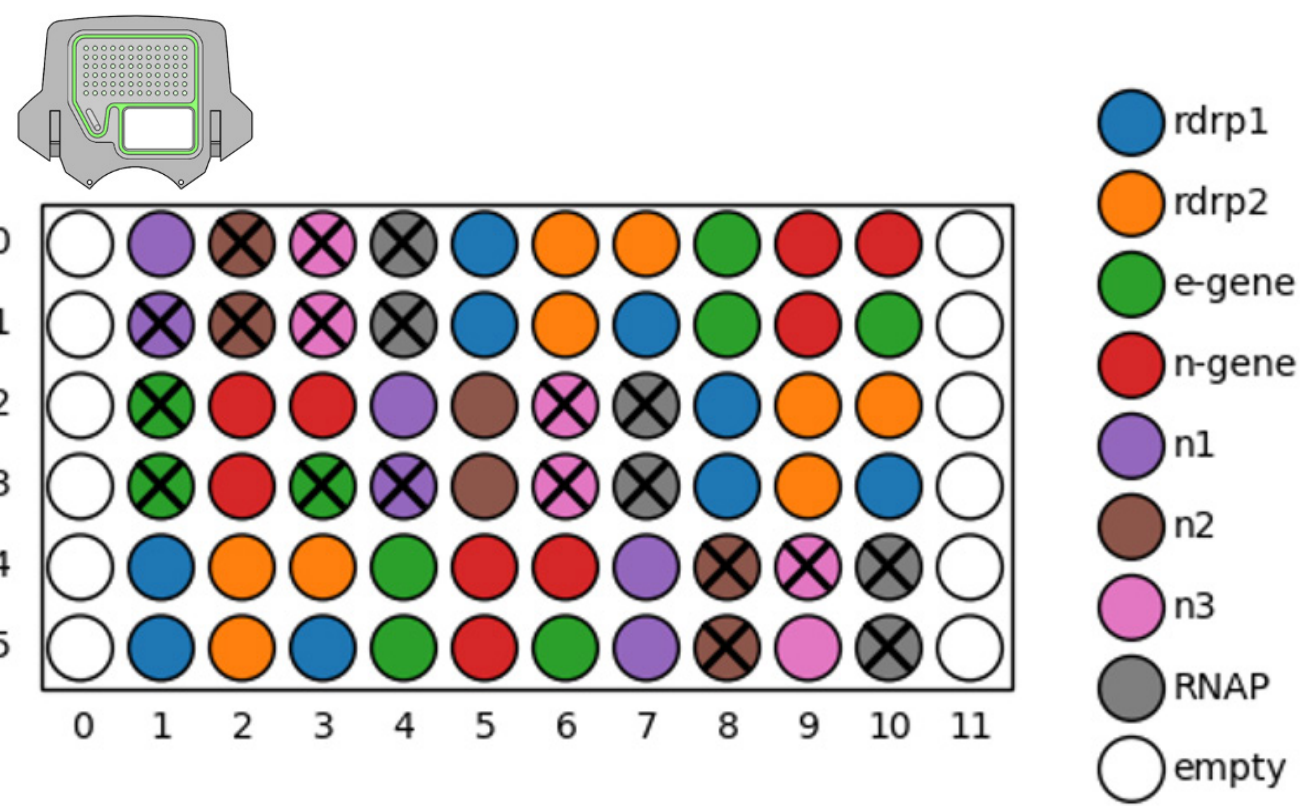
Laboratory samples not recorded

( $n=43)$

\section{Paired Samples $(n=418)$}

Invalid Samples

(DnaNudge) $(\mathbf{n}=\mathbf{2 4})$

Invalid Samples

(NHS Lab) $(\mathrm{n}=8)$

Valid samples $(\mathbf{n}=386)$

Group 1

Symptomatic Staff Testing

$$
(n=280)
$$
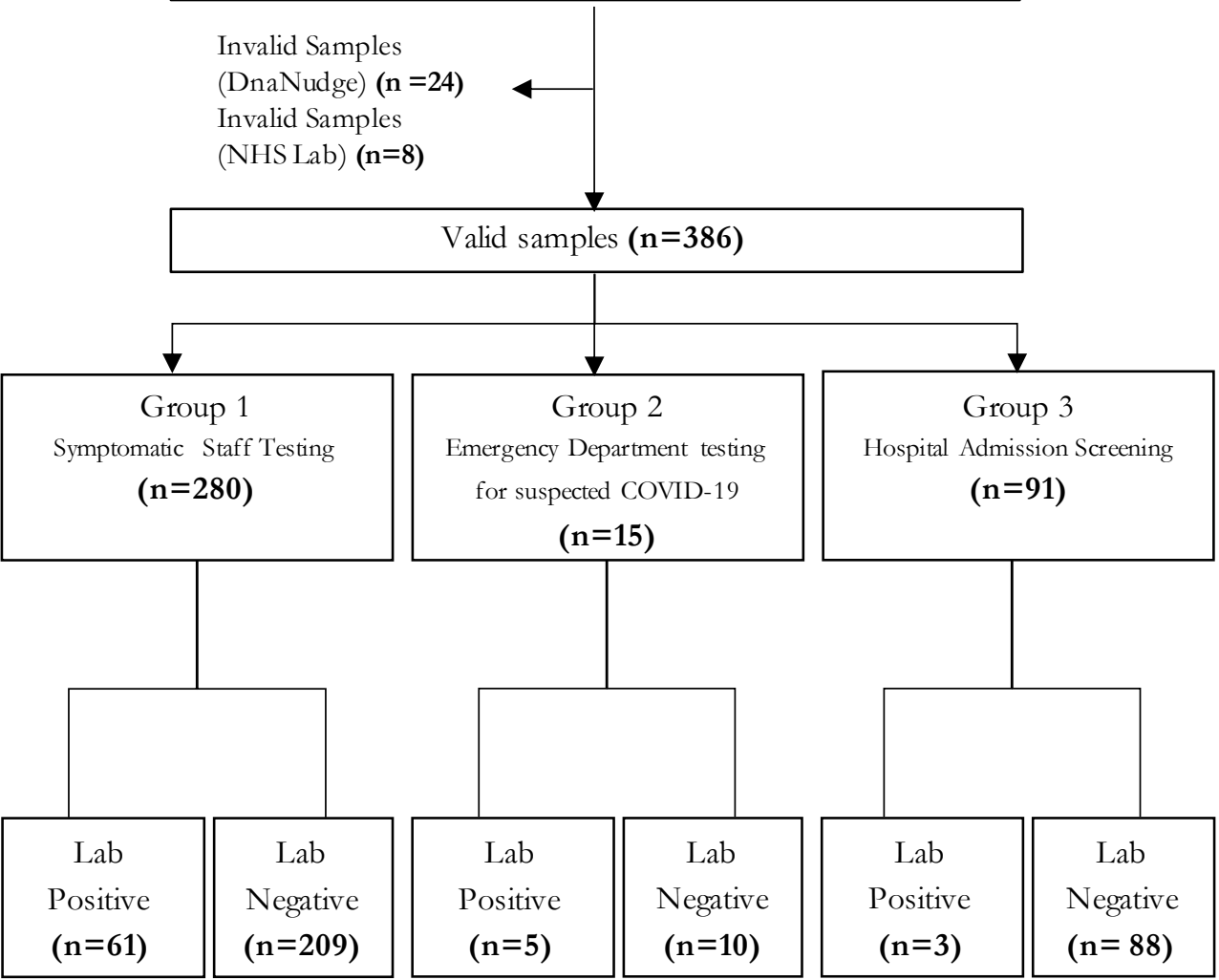
